INEEL/EXT-2000-01441

December 2000

\title{
Demonstration of Decision Support Tools for Sustainable Development
}

An Application on Alternative Fuels in the Greater Yellowstone-Teton Region
D. E. Shropshire
D. A. Cobb
P. Worhach
J. J. Jacobson
S. Berrett 


\title{
Demonstration of Decision Support Tools for Sustainable Development
}

\section{An Application on Alternative Fuels in the Greater Yellowstone-Teton Region}

\author{
David E. Shropshire (INEEL) \\ David A. Cobb (Bechtel National, Inc.) \\ Paul Worhach (Nexant LLC) \\ Jake J. Jacobson (INEEL) \\ Sharon Berrett (INEEL)
}

Published December 2000

Prepared for Bechtel National Inc.

Work for Others Agreement 00-830

Bechtel Job 90957-003 
The Dynamic Industrial Materials Exchange (DIME) and the Industrial Materials Exchange Planner (IMEP) discussed in this report are a copyright of Bechtel National, Incorporated, 2000. All rights reserved. 


\begin{abstract}
The Demonstration of Decision Support Tools for Sustainable Development project integrated the Bechtel/Nexant Industrial Materials Exchange Planner and the Idaho National Engineering and Environmental Laboratory System Dynamic models, demonstrating their capabilities on alternative fuel applications in the Greater Yellowstone-Teton Park system. The combined model, called the Dynamic Industrial Material Exchange, was used on selected test cases in the Greater Yellow Teton Parks region to evaluate economic, environmental, and social implications of alternative fuel applications, and identifying primary and secondary industries. The test cases included looking at compressed natural gas applications in Teton National Park and Jackson, Wyoming, and studying ethanol use in Yellowstone National Park and gateway cities in Montana. With further development, the system could be used to assist decision-makers (local government, planners, vehicle purchasers, and fuel suppliers) in selecting alternative fuels, vehicles, and developing AF infrastructures. The system could become a regional AF market assessment tool that could help decision-makers understand the behavior of the AF market and conditions in which the market would grow. Based on this high level market assessment, investors and decision-makers would become more knowledgeable of the AF market opportunity before developing detailed plans and preparing financial analysis.
\end{abstract}




\section{CONTENTS}

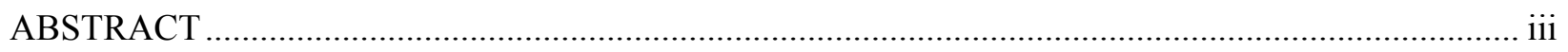

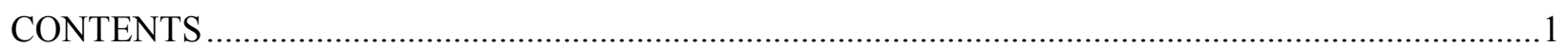

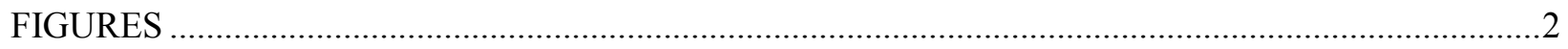

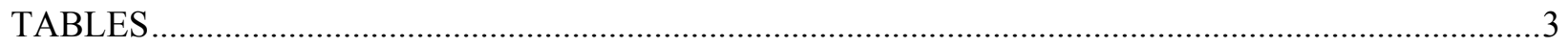

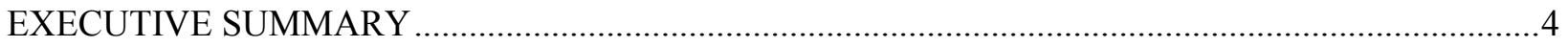

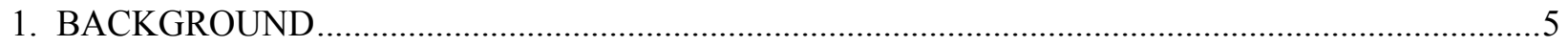

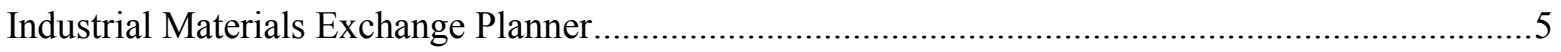

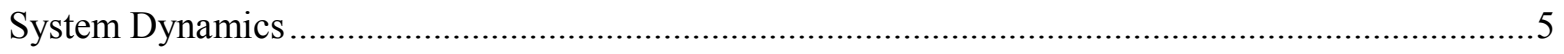

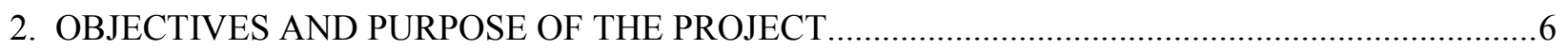

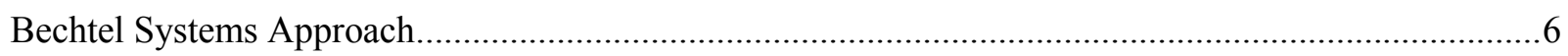

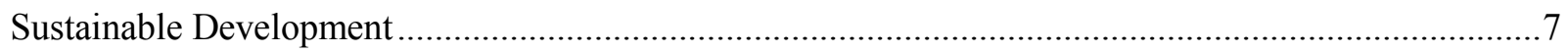

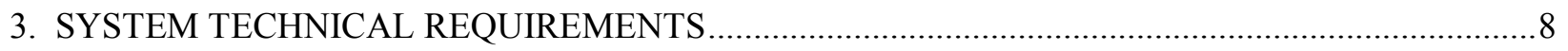

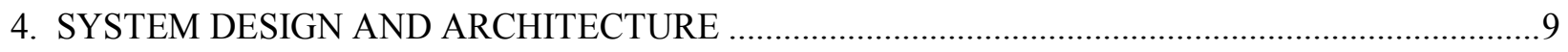

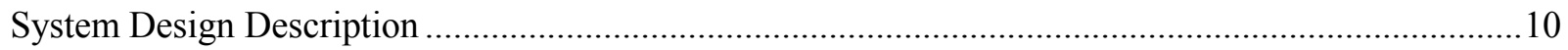

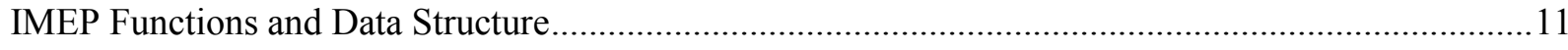

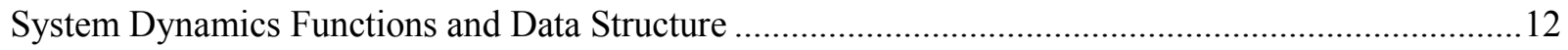

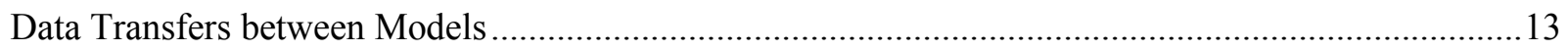

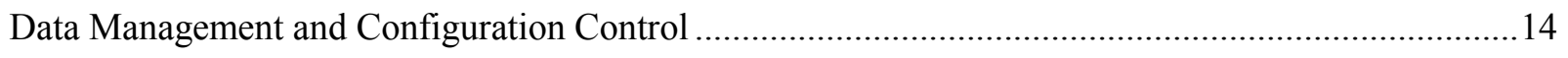

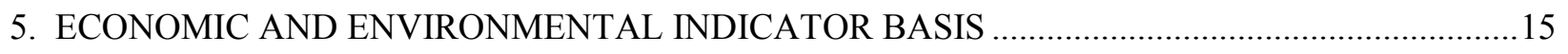

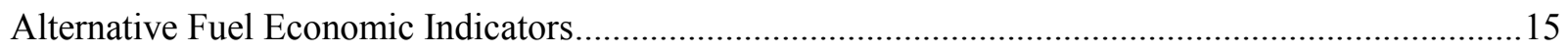

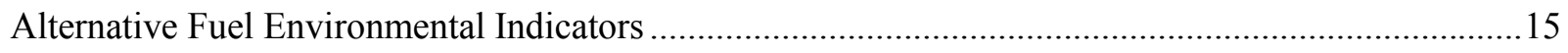

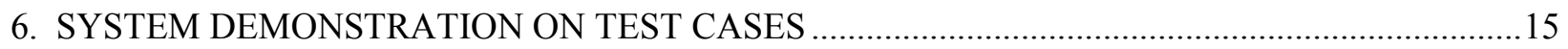




\section{Demonstration of Decision Support Tools for

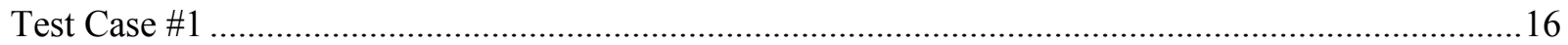

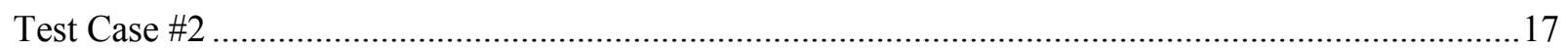

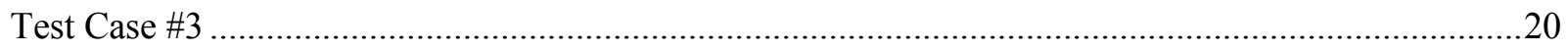

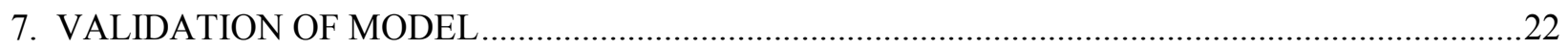

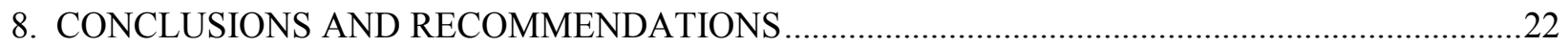

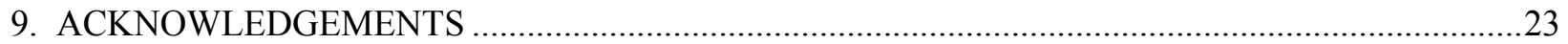

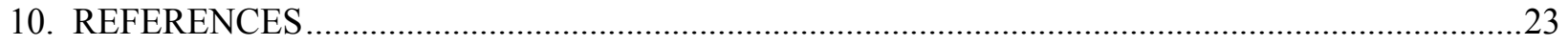

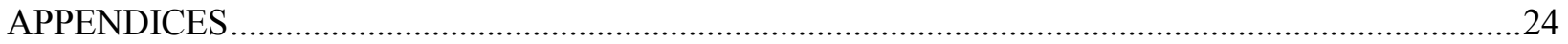

Appendix A —-Industrial Material Exchange Model Description..........................................................24

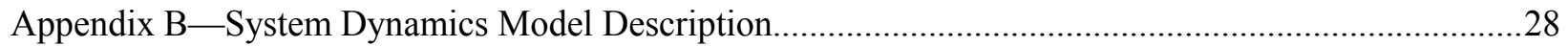

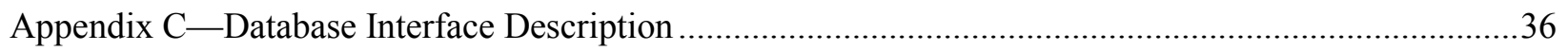

Appendix D_Alternative Fuel Emissions Estimation Basis.............................................................40

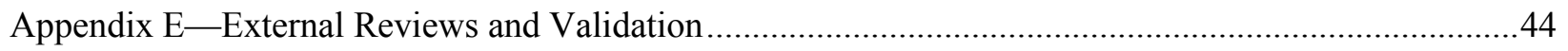

\section{FIGURES}

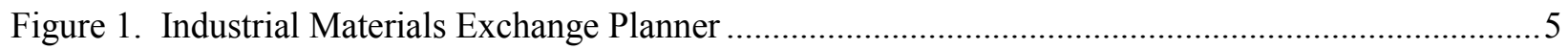

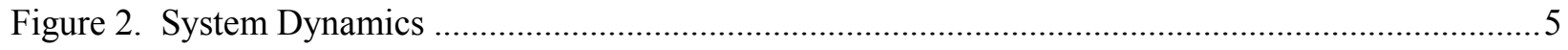

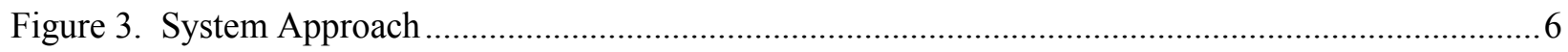

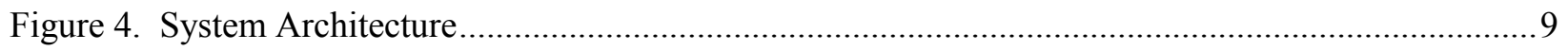

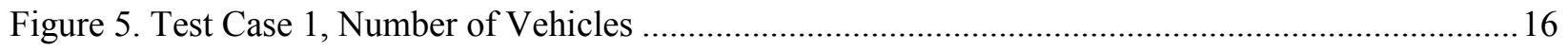

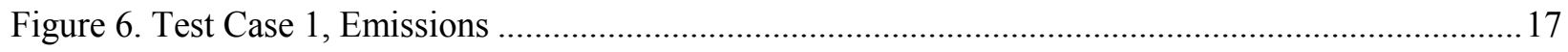

Figure 7. Test Case 2, Number of Vehicles................................................................................. 18

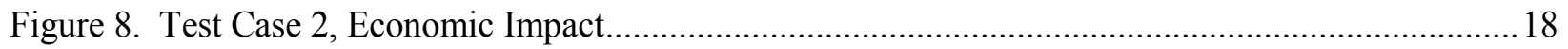

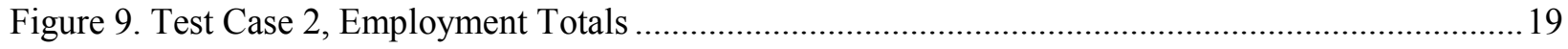




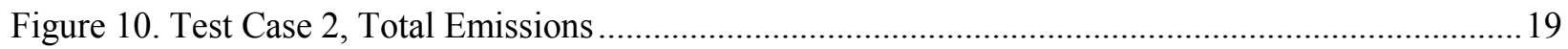

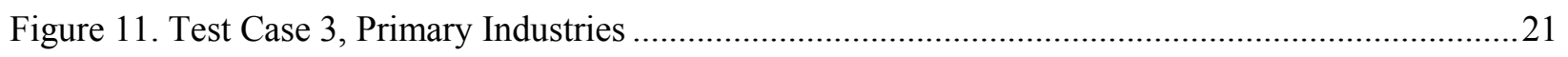

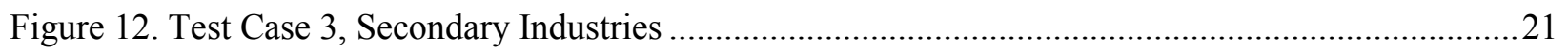

\section{TABLES}

Table 1: Some Key IMEP Data Sources for Ethanol Production...................................................... 11

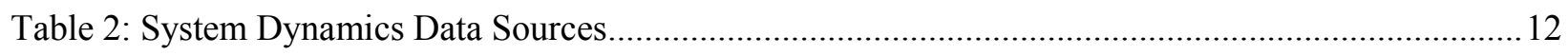

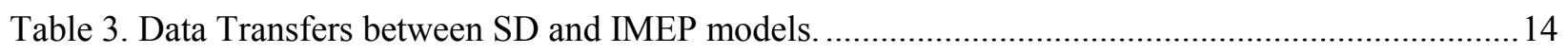

Table 4. Examples of IMEP data transfers to the SD model............................................................... 14 


\section{Demonstration of Decision Support Tools for Sustainable Development}

\section{EXECUTIVE SUMMARY}

The purpose of the Demonstration of Decision Support Tools for Sustainable Development project was to integrate the Bechtel/Nexant Industrial Materials Exchange Planner and the Idaho National Engineering and Environmental Laboratory System Dynamic models, and then to demonstrate their capabilities on three hypothetical alternative fuel (AF) applications in the Greater Yellowstone-Teton Park system. The integrated model, called the Dynamic Industrial Material Exchange, was used to evaluate the economic, environmental, and potential social implications from alternative fuel applications. This report describes the objectives, methods, procedures, results and conclusions from the project.

The project evaluated the market growth potential and identified primary and secondary industries for selected test cases in the Greater Yellowstone Teton Parks region. The test cases included looking at compressed natural gas applications in Teton National Park and Jackson, WY, and ethanol use in Yellowstone National Park and gateway cities in Montana. A systems approach was used to determine the technical requirements for the system and convert these requirements into a system design. Industry

data was collected that defined the input/output profiles for industries that produce ethanol. Data was also collected for current energy usage and information that could be used to estimate the potential alternative fuel market. The system was designed to handle future expandability for other alternative fuels, geographic locations, and increased system complexity.

The integration of the IMEP and SD tools was successfully demonstrated on test cases involving the evaluation of alternative fuels in the Greater Yellowstone Teton region. With further development and verification, the system could also be used to assist decision-makers (local government, planners, vehicle purchasers, and fuel suppliers) in selecting alternative fuels, vehicles, and developing AF infrastructures. The system could become a regional AF market assessment tool that could help decision-makers understand the behavior of the AF market and conditions in which the market would grow. Based on this high level market assessment, investors and decision-makers would become more knowledgeable of the AF market opportunity before developing detailed plans and preparing financial analysis.

The audience for this report is Bechtel National Inc. and associates including Nexant, Inc., the National Renewable Energy Laboratory, the Greater Yellowstone Teton Systems Program, DOE laboratories, the National Park Service and Clean Cities Coalitions, and industries supporting alternative fuel and bioproduct development and deployment. 


\section{Demonstration of Decision Support Tools for Sustainable Development}

\section{BACKGROUND}

\section{Industrial Materials Exchange Planner}

Over the past several years Bechtel National Inc. (BNI) has developed, in collaboration with Nexant, Inc., a proprietary planning model called the Industrial Materials Exchange Planner (IMEP) intended to help the design of integrated industrial complexes characterized by multiple closed exchange loops of products, by-products, and wastes (Figure 1). The goal of such an exchange is to reduce the volume of waste and pollution, reduce transportation and waste treatment costs, and reduce net consumption of natural resources. The IMEP is also able to identify opportunities for new businesses that could take advantage of materials available and needed within the system. The IMEP has been used in preliminary design and planning of a number of Bechtel projects ranging from the Jubail Industrial Complex to a waste reduction program designed for a complex of regional businesses in Tampico, Mexico.

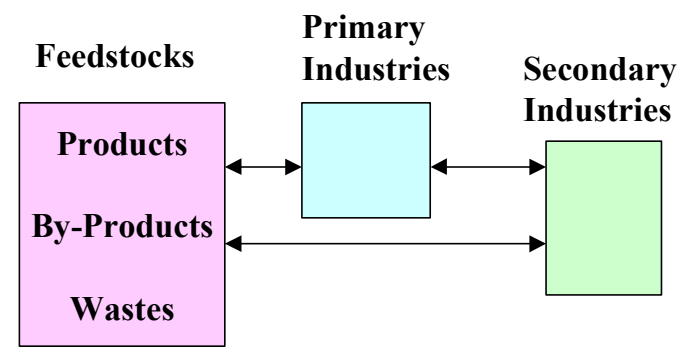

Figure 1. Industrial Materials Exchange Planner

\section{System Dynamics}

The Idaho National Engineering and Environmental Laboratory (INEEL) has developed applications using a powerful tool developed by Massachusetts Institute of Technology called System Dynamics (SD). $\mathrm{SD}$ is an analytic approach that examines complex systems through the study of the underlying system structure. An example of a complex structure is the alternative fuel market and its impacts on alternative fuel economics and the environment (Figure 2). The INEEL has developed SD models to investigate: transmission of hazardous waste from its sources through the aquifer, future sustainability issues for the Wasatch Front Range water supplies; and carbon mitigation alternatives including use of energy efficiency and sustainable development mechanisms.

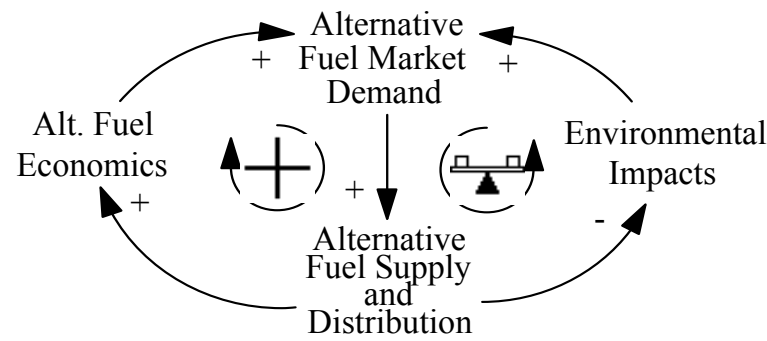

Figure 2. System Dynamics 


\section{Demonstration of Decision Support Tools for Sustainable Development}

\section{OBJECTIVES AND PURPOSE OF THE PROJECT}

The objective of this report is to describe the objectives, methods, procedures, results and conclusions from the Corporate Funded Research and Development (CFRD) Project on the Demonstration of Decision Support Tools for Sustainable Development.

The project was sponsored by BNI to integrate and demonstrate the application of the IMEP model with the Idaho National Engineering and Environmental Laboratory (INEEL) SD model. The combined model is referred to in the text as the "Dynamic Industrial Materials Exchange" or "DIME" model. Successful application of DIME on a representative application may lead to future applications within BNI and for other customers, including its use to support sustainable development projects globally.

The audience for this report is BNI and associates including Nexant, Inc., National Renewable Energy Laboratory (NREL), the INEEL Greater Yellowstone Teton Systems Program, DOE laboratories, the National Park Service and Clean Cities Coalitions, and industries supporting alternative fuel and bioproducts development and deployment.

The study area chosen to demonstrate these tools was the regional alternative fuel systems in the Greater Yellowstone Teton (GYT) region. The objective of this application was to demonstrate decision support tools to provide decision makers (local government, planners, vehicle purchasers, fuel suppliers) information to help support specific decisions on selecting alternative fuels, vehicles, and infrastructures for a variety of applications.

\section{Bechtel Systems Approach}

This project followed the Bechtel National Inc. Systems Approach including requirement analysis, functional analysis/allocation, trade studies, and synthesis (Figure 3). A Technical Requirements Document (TRD) was developed to provide the upward and downward traceablility of requirements from the overall objective, including the system description and customer expectations, the modeling test cases, technical and functional requirements, and identification of the data needs.

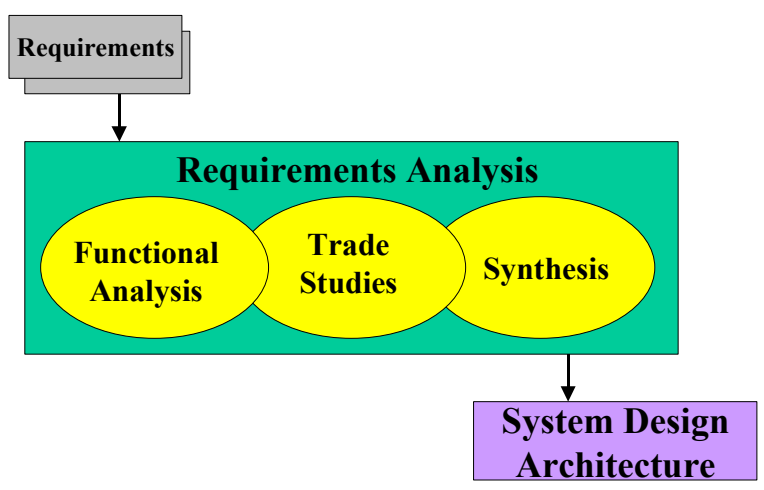

Figure 3. System Approach 


\section{Demonstration of Decision Support Tools for Sustainable Development}

\section{Sustainable Development}

This assessment of alternative fuel includes the factors that contribute toward Sustainable Development. These factors include considering environmental impacts, local community (social) interests, and economics. Sustainable development implies local self-reliance, which, in part, is measured by the dollars and jobs kept in the local economy vs. exported (i.e., to fuel refiners and producers outside the GYT region). The concept also implies the use renewable energy (e.g., ethanol, and biodiesel).

- Environmental Impacts - The analysis will provide output of annual greenhouse gas emissions from AFs compared to petroleum based fuels. (The current analysis will include environmental impacts from vehicle use but not from production.)

- Social or Socio-Economic Impacts - Impacts will be identified for primary industries and job creation in local communities. The agriculture lands needed to support AF production (switching between crop types, agriculture practices, etc.) will be estimated.

- Economic Impacts - The potential annual revenue generated from alternative fuel primary and secondary industries will be estimated. The need for new AF businesses will be identified and linked to the existing mix of businesses in the GYT region. New business sources that could produce feedstocks for the AF system and use byproducts created by the AF system will be identified.

\footnotetext{
1 'The concept of sustainable development was first proposed in 1972 at the United Nation's Conference on the Human Environment, yet it was not until 1987 that sustainable development became a policy goal. In a report to the United Nation's World Commission on Environment and Development, Norway's Prime Minister Gro Harlem Brundtland defined sustainable development as "meeting the needs of the present without compromising the ability of future generations to meet their own needs". Although this definition was vague in nature, the 1992 Conference on Environment and Development in Rio de Janeiro refined the concept. Agenda 21 claimed that countries must "seek the mutual goals of economic development and environmental protection for the purpose of fulfilling the basic needs for all". Since then other environmental, political, and industrial groups have modified this definition to encompass a variety of interactions between humans and their use of the Earth's resources.' Source: American Geol. Inst., Gov't Affairs Program, June 19, 1998. Update on the President's Council on Sustainable Development.
} 


\section{Demonstration of Decision Support Tools for Sustainable Development}

\section{SYSTEM TECHNICAL REQUIREMENTS}

The system technical requirements were derived from customer expectations for analysis capabilities to address key sustainability factors (i.e., economic, environmental, social) that may influence the use of AF's). These requirements provide the basis for the system design specification. Key analysis capabilities include understanding the AF market growth and capacity limitations; factors that could lead to conversion to AF's; current fuel use; and potential AF markets. The requirements for this study that are outlined below were selected to fit within the scope, schedule, and costs for this demonstration of decision support tools. A complete listing of the requirements that would be needed to develop an ideal alternative fuels system is provided in the TRD document (Shropshire, September 2000).

1. System Definition. The study will include an evaluation of ethanol (E95) and Compressed Natural Gas (CNG) fuels in the Grand Teton National Park, Yellowstone National Park and gateway cities in Wyoming and Montana. Alternative fueled vehicles (AFV) were selected for the demonstration. The AF infrastructure will include agriculture crop producers. The TRD also identifies other GYT sub-regions, alternative fuels (i.e., biodiesel, LNG, propane) and related products (e.g., electric and electric-hybrid vehicles), and AF infrastructure elements that could be included in future model development.

2. Alternative Fuel Market Growth and Capacity Analysis. The system will provide dynamic modeling of market growth and capacity building of AF's including supply, demand and pricing utilities. The system will evaluate the AF system requirements and capacity constraints including processing inputs and outputs. The current AF capacities will be assessed as well as the time required for increasing capacities. The agriculture requirements for production of AFs (i.e., acres of land required based on crop yields) will be calculated.

3. Factors That Could Lead to Conversion to Alternative Fuels. The factors that could lead to conversion to AFs will be identified. The types of factors may include the affects of incentives or mandates (legislation) that require a minimum percentage of AF usage. Utility functions will be used to evaluate tradeoffs between factors for conventional fuel and alternative fuel that can influence the market share of AFs (i.e., fuel availability, horsepower and efficiency, vehicle ranges, economic indicators such as vehicle purchase price and alternative fuel cost, and environmental indicators such as greenhouse gas emissions). The effect of petrofuel prices on consumer demand will also be considered.

4. Current Baseline Energy Use. Baseline data will be used that reflect the current fuel/energy use (how much fuel is used, of what type, at what cost). The total fuel usage's by type (gasoline, CNG, ethanol) will be identified by county (e.g., Teton county) and GYT subregions. Alternative fuel stations for CNG will provide the number in the park and the number planned.

5. Potential Alternative Fuel Market. The baseline data will be used to estimate the potential AF market. The baseline information should include the numbers of vehicles in the gateway communities and the national parks, and current AF vehicles. Other data may be collected that could be used to estimate the future market size. This data includes the population and growth rates of gateway communities (past, current, projected) park visitor rates by people and cars (past, current, projected), and hotel usage rates (number of guests/year). 


\section{Demonstration of Decision Support Tools for Sustainable Development}

\section{SYSTEM DESIGN AND ARCHITECTURE}

The technical system requirements were converted into the design architecture through functional decomposition and synthesis activities.

1. Functional decomposition is a process where the requirements are allocated into functions that the system must perform. Once the functions are determined, performance levels are defined and the interfaces between functions are defined.

2. The synthesis activity defines the system architecture. Synthesis is conducted to define system elements and to refine and integrate them into a physical configuration of the system that satisfies functional and performance requirements.

The system architecture defines the interfaces between the high-level physical system components (i.e., Industrial Material Exchange, System Dynamics) and partitions the functional components between the models. The system architecture provides the basis for the design and allocation of requirements to the model platform (software). The system architecture developed for the DIME is shown in Figure 4.

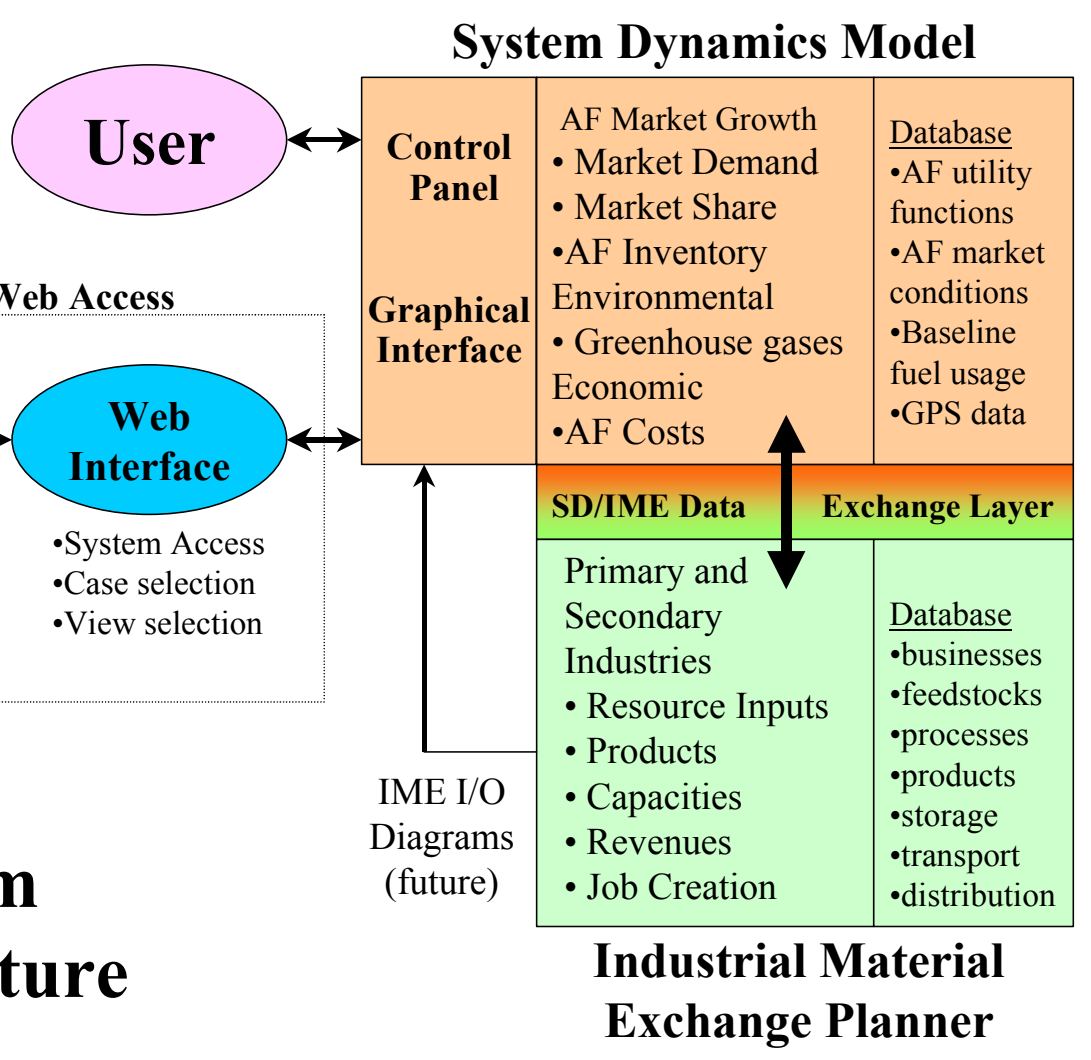

Figure 4. System Architecture 


\section{Demonstration of Decision Support Tools for Sustainable Development}

\section{System Design Description}

The preferred design selected was an integrated model consisting of the Industrial Materials Exchange and System Dynamics models connected by a seamless system interface, a common data storage device, and a graphical user interface. The design team determined that this system would be well suited for meeting the system functional requirements.

Bechtel/Nexant's IMEP model could be integrated with the INEEL's SD models to demonstrate a capability to support sustainable development. The DIME may be used to develop feasible and effective solutions to regional needs for reduced air emissions, and improved energy efficiency and increased socioeconomic benefits within a specific study region.

The models will be used to provide quick interactive analysis of AF scenarios to analyze new business opportunities, technologies, economics and environmental impacts. A user-interface with a control panel and graphical outputs will provide interactive "what-if" analysis. Users will be provided with ability to adjust key system variables (initial fuel prices, market size, AF adoption rates, production cycle time and construction delays). Project scenarios will capture fixed and variable costs for a specific fuel selection. Users will be able to perform trade offs between and within these scenarios using different assumptions. The analysis capabilities will begin in 1999 and running for at least 20 years.

The system should produce output charts and reports including: historical trends and relationships for total fuel usage (e.g., gallons used), agriculture footprints, greenhouse gas emissions, cost, primary and secondary industries, AF capacities, number of conventional and AF vehicles, AF inventory, and AF conversion utilities.

The system is intended to be primarily a system analysis tool. The model will support analysis of trends and help predict how the system will react to change. The system can be studied to gain critical insights on the effects from system perturbations, use of AF technologies, population growth, energy demand, and other influences. Often the outcomes from these types of studies produce nonintuitive results. This is due to the difficulty of the human mind to process and comprehend nonlinear relationships with feedback loops between multiple systems. Computer models can be used to handle this complexity and carry out more simultaneous calculations than can the human mind.

Modeling development will be performed through a versatile, expandable programming environment. System development will be performed on stand-alone PC's. The computer code will be configuration controlled by periodically archiving the code by date control. 


\section{Demonstration of Decision Support Tools for Sustainable Development}

\section{IMEP Functions and Data Structure}

The IMEP is a database, scenario development, and optimization tool that matches product, by-product, and waste streams that have technical and positive potential for linkage with feedstock requirements. The IMEP also identifies new business opportunities that can link with existing use and production of materials in a region.

For each new project, building the database for the study site is the fundamental part of the IMEP work. A process profile of individual businesses existing at a study site is prepared. This profile includes material flow streams such as raw materials, products, by-products, and wastes. Information regarding utilities, manpower and other nontechnical data can also be included. These project-specific industry profiles are then merged with a proprietary Global Industry Database comprised of input/output profiles from over 380 different industrial processes, from refineries to agricultural operations. The database also contains generic profiles for a wide range of recycling processes.

Data sources include but are not limited to articles in the professional literature, articles in conference proceedings, interviews with staff of manufacturing facilities and a variety of trade group, government, and individual company sites on the World Wide Web (www). Literature and conference references are listed in the "Reference Documents" section of this report. Personal conversations are cited on the individual company profiles contained in the IMEP database. Key www sites providing AF fuels data and information for this study as listed in Table 1.

Table 1: Some Key IMEP Data Sources for Ethanol Production

\begin{tabular}{|l|l|}
\hline \multicolumn{1}{|c|}{ Data Source } & \multicolumn{1}{c|}{ Data Type/Description } \\
\hline $\begin{array}{l}\text { American Coalition for Ethanol } \\
\text { (ACE): www.ethanol.org }\end{array}$ & $\begin{array}{l}\text { Ethanol promotion site. Many links to producers and other } \\
\text { sources of data including individual State programs and } \\
\text { sites. Good place to start ethanol search. }\end{array}$ \\
\hline $\begin{array}{l}\text { Arkenol Corporation: } \\
\text { www.arkenol.com }\end{array}$ & $\begin{array}{l}\text { "Building a chemical company that is looking to the sugar } \\
\text { barrel instead of the oil barrel for our feedstocks." Describes } \\
\text { proprietary concentrated acid hydrolysis process for biomass } \\
\text { conversion to ethanol. Planned project in Sacramento, CA. }\end{array}$ \\
\hline $\begin{array}{l}\text { Ethanol Producers and Consumers } \\
\text { (EPAC): www.ethanolmt.org }\end{array}$ & $\begin{array}{l}\text { Site of Ethanol Producers and Consumers. Promotes use of } \\
\text { ethanol fuels. Links to individuals and organizations active } \\
\text { in ethanol production and use. Map of current ethanol sites. }\end{array}$ \\
\hline $\begin{array}{l}\text { Renewable Fuels Association } \\
\text { (RFA): } \text { www.ethanolrfa.org }\end{array}$ & $\begin{array}{l}\text { Trade organization site dealing with a variety of alternative } \\
\text { fuels. Limited list of links to other relevant sites. }\end{array}$ \\
\hline $\begin{array}{l}\text { USDA Biofuels Site: } \\
\text { www.nal.usda.gov/ttic/biofuels.htm }\end{array}$ & $\begin{array}{l}\text { Especially useful for its links through "Biofuels Resources } \\
\text { in the Internet" listing USDA, other government, and private } \\
\text { sources of information. }\end{array}$ \\
\hline $\begin{array}{l}\text { Nebraska Ethanol Board: www.ne- } \\
\text { ethanol.org/ }\end{array}$ & $\begin{array}{l}\text { Includes info on a number of Nebraska ethanol producers } \\
\text { including production data and personal contacts for } \\
\text { additional details. }\end{array}$ \\
\hline
\end{tabular}




\section{Demonstration of Decision Support Tools for Sustainable Development}

\begin{tabular}{|l|l|}
\hline $\begin{array}{l}\text { USDOE, NREL Alternative Fuels } \\
\text { Data Center: } \\
\text { www.afdc.nrel.gov/related.html }\end{array}$ & $\begin{array}{l}\text { Another good source of AF information with many useful } \\
\text { links including State sites. }\end{array}$ \\
\hline
\end{tabular}

The IMEP database, currently in Microsoft Access, is searched to identify a network of existing and potential new businesses linked by common feedstocks, products, and wastes. Alternatively, the database can be searched to track a single commodity, or a mix of commodities, used and produced within a region. The project planner assesses the technical feasibility of the exchange and recycling opportunities identified in the IMEP scenarios, and selects promising candidates from the list of new and complementary businesses selected from the generic industry profile. Additional details on the IMEP design, including linkages between upstream and downstream processes and products are shown in Appendix A.

\section{System Dynamics Functions and Data Structure}

A common (Microsoft Access) database will be used to store and share information. The data requirements will be based on input from various data sources shown in Table 2. Data requirements will be fulfilled through literature searches and detailed site-specific data collection and system input to a database. The database user interface and data entry/view menus are described in Appendix C.

Table 2: System Dynamics Data Sources

\begin{tabular}{|l|l|}
\hline \multicolumn{1}{|c|}{ Data Source } & \multicolumn{1}{|c|}{ Data Type/Description } \\
\hline U. S. Census Bureau, U. S. Department of Commerce & Population information \\
\hline U.S. Department of Agriculture & Current farm land and crops \\
\hline Federal Register Volume 65 No. 81, April 26, 2000 & Executive Order's governing AF \\
\hline $\begin{array}{l}\text { Greater Yellowstone/Teton Clean Cities Coalition, Market } \\
\text { Development \& Clean Cities Action Plan, April 2000 }\end{array}$ & $\begin{array}{l}\text { Current (1999) and projected AFV } \\
\text { Market (2000-2004) }\end{array}$ \\
\hline $\begin{array}{l}\text { CNN.Com October 26, 1997 } \\
\text { http://www.cnn.com/US/9710/26/briefs.pm/gas.prices/ }\end{array}$ & Average 1997 gas prices \\
\hline $\begin{array}{l}\text { Executive Order 13149 - Greening the Environment through } \\
\text { Park County }\end{array}$ & Number of vehicles in Park County \\
\hline Park County Montana Department of Motor Vehicles & Transportation Efficiency \\
\hline Teton County Wyoming Department of Motor Vehicles & $\begin{array}{l}\text { Current number of registered } \\
\text { vehicles in Teton County }\end{array}$ \\
\hline $\begin{array}{l}\text { Regional Economics Assessment Database (READ) System, } \\
\text { University of Montana }\end{array}$ & $\begin{array}{l}\text { Number of fueling stations and } \\
\text { amount of fuel sold in each county. }\end{array}$ \\
\hline
\end{tabular}




\section{Demonstration of Decision Support Tools for Sustainable Development}

The system can be used to analyze AF market opportunities. Capabilities include the manipulation of key variables of predefined use cases and graphical display of system outputs (e.g., supply and demand of AFs, new businesses created, air emissions).

The impacts from incentives (or mandates) for AF use is provided through a graduated scale from no incentives to low, medium, and high incentives, corresponding to levels of $10 \%, 20 \%$, and $30 \%$ respectively.

The market growth model contains two components that represent the basic structure that would influence the market growth of a commodity, in this case, alternative fuel. Those two components are "Order Fulfillment" and "Capacity Acquisition". The combination of these two components strongly influence the behavior of the customers and hence their demands for the product. Long delivery delays and shortages, reduced performance of alternative fuels, and high costs will drive customers to other substitution products. On the other hand, low costs and easy acquisition will draw customers to the market.

Order fulfillment and capacity acquisition can also strongly influence each other. For instance, too much supply would drive the price of the commodity down which effects profit. Low profits generally drive the producers to produce less. Less production drives supply down, which eventually drives the price back up. However, the inherent delays, recognition of low profits, backlog, high inventories, in the system usually cause a self-inflicted oscillation of price, supply and production. Furthermore, large oscillations can cause over-capacity and employment fluctuations in the AF sector.

Using the model, managers can become aware how their behaviors are actually causing the oscillations that they are trying to avoid. Performing gaming or what-if scenarios on capacity increases, commodity price, inventory coverage and supply times allows the managers to experiment with different management strategies and receive real time feedback of the consequences.

Additional details on the system dynamics model design, including the market growth relationships and utility functions are provided in Appendix B.

\section{Data Transfers between Models}

At each time step in the planning horizon, Systems Dynamics model passes a fuel type (such as "Ethanol" or "Compressed Natural Gas") and a total system demand (1,000,000 gallons) for the fuel. The IMEP model sends a query to its industry profile databases, returning the profiles of the primary producers of the fuel, as well as all secondary upstream or downstream industries in the fuel production chain. Based upon the capacity of a company represented in the process profiles, IMEP estimates the number of facilities (or land acreage, in the case of an agricultural operation) required to meet the specified demand from a particular production process. IMEP also estimates the total economic impact (in terms of gross revenue and total employment) from each primary industry and each secondary industry based upon the level of demand. It is important to note that IMEP reports all matching profiles in its database, assuming that each process or each farm, scaled up appropriately, could meet the entire demand. A summary of the data transferred between the SD and IMEP models is shown in Table 3. Examples of the type of data generated by IMEP are provided in Table 4. 


\section{Demonstration of Decision Support Tools for Sustainable Development}

Table 3. Data Transfers between SD and IMEP models.

\begin{tabular}{|c|c|}
\hline Data Passed From SD to IMEP: & Data Passed from IMEP back to SD: \\
\hline $\begin{array}{l}\text { Data element: } 2 \mathrm{xN} \text { array, where } \mathrm{N} \text { is the number of } \\
\text { fuels. }\end{array}$ & $\begin{array}{l}\text { Data element: } 7 \mathrm{xM} \text { array, where } \mathrm{M} \text { equals } \\
\text { (primary and secondary businesses) * (number of } \\
\text { outputs). }\end{array}$ \\
\hline $\begin{array}{l}\text { An element of the array is: } \\
\text { Fuel, } \\
\text { Fuel Demand. } \\
\text { (Units for ethanol are in gallons.) } \\
\text { (Units for CNG are in thousand-cubic-feet.) } \\
\text { For any additional fuels passed to IMEP, the units } \\
\text { must be agreed upon in advance between IMEP and } \\
\text { SD. }\end{array}$ & $\begin{array}{l}\text { An element of the array is: } \\
\text { Industry Type, } \\
\text { Primary" or "Secondary" Industry Output, } \\
\text { Required Physical Capacity, } \\
\text { Unit Type of Physical Capacity, } \\
\text { Monetary Value of Output, } \\
\text { Required Employment. } \\
\text { Example: a farm could have two outputs, alfalfa } \\
\text { and corn. These world be represented by two } \\
\text { records.\} }\end{array}$ \\
\hline
\end{tabular}

Table 4. Examples of IMEP data transfers to the SD model.

\begin{tabular}{|l|l|}
\hline \multicolumn{1}{|c|}{ Example: Industry Type $=$ Farming } & \multicolumn{1}{c|}{ Example: Industry Type $=$ Distillation } \\
\hline Primary/Secondary=Primary & Primary/Secondary=Primary \\
Primary Industry Output $=$ Alfalfa & Primary Industry Output $=$ Ethanol \\
Physical Unit $=5,000$ & Physical Unit $=35,700,000$ \\
Unit Type $=$ acres & Unit Type $=$ gallons $/$ year (plant capacity) \\
Monetary Units $=\$ 500,000$ & Monetary Units $=\$ 35$ million \\
Employment $=45$ & Employment $=35$ \\
& \\
\hline
\end{tabular}

\section{Data Management and Configuration Control}

Data will be collected and retrievably stored including AF usage data; potential customer demand (derived from regional populations and park visitors); AF processing inputs/outputs, storage, and fuel distribution data; AF costs, regional environmental data and bioproduct market information. The interface between systems will allow data exchange and graphical display of information. Data may be accessed on a county, GYT region, or subregions.

All system data will be defined, stored, and controlled. Data configuration control will encompass input of data, data relations, constraints, and assumptions. Data must be able to be preserved and managed to support use case management. Data sets will be configuration controlled by periodically archiving data by date control. Data for a base case representing the current use of AF's and petrofuel will be collected and used for case comparison. 


\section{ECONOMIC AND ENVIRONMENTAL INDICATOR BASIS}

\section{Alternative Fuel Economic Indicators}

For this study, relative economic indicators were used to evaluate fuel price sensitivity. The retail cost for ethano 2 was modeled at $\$ 2.50$ per gallon and at $\$ 1.65$ per gallon for CNG. These costs were estimated based on a limited fuel supply and infrastructure available in the GYT region to support market growth. A revenue value of $\$ 1.00$ per gallon was used to estimate regional economic impact.

Winter wheat prices were assumed to be $\$ 2.25$ a bushel, or approximately $\$ 191.00$ a ton. Production was assumed to be 39.5 bushels/acre (10-year average of U. S. National winter wheat prices obtained from USDA grain and feed statistics for the period 1989 - 1999, available at www.usda.gov/nass). Ethanol yield per bushel is approximately 2.4 gallons/bushel, or 98.8 gallons/acre.

\section{Alternative Fuel Environmental Indicators}

The bases for the AF vehicle emissions for conventional and alternative fuels are based on non-stationary applications. All emissions result in units of grams of Carbon Dioxide Equivalent (CDE) which account for greenhouse gas emissions with relevant global warming potential factors applied $\left(\mathrm{CO}_{2}=1.0, \mathrm{CH}_{4}=\right.$ $21, \mathrm{~N}_{2} \mathrm{O}=310$ ). Details on the emissions bases for non-stationary and stationary (not used in this assessment) fuel users are contained in Appendix D.

Greenhouse gas emissions (in CDE units) are calculated for non-stationary sources based on a per mile usage rate. Greenhouse gas emissions include fuel cycle energy use from feedstock generation, fuel processing, and vehicle operation based on passenger car vehicles.

\section{SYSTEM DEMONSTRATION ON TEST CASES}

The DIME was used to analyze various alternative fuels (ethanol, CNG, and related products) at various geographic sites/locations in the GYT region. DIME was applied to analysis of scenarios that could be used for sustainability planning in the GYT region. The criteria used to select the test cases for the demonstration were based on:

1. Project requirements (customer interest, project funding, schedule constraints)

2. Sustainable development requirements (provide economic, environmental, social impacts)

3. Model demonstration requirements (show integration of IMEP and SD models). This included dynamic market behavior, and identification of upstream and secondary industries associated with the alternative fuels.

\footnotetext{
${ }^{2}$ Current ethanol prices in areas with an existing alternative fuel infrastructure are $\$ 1.70$ per gallon at the pump for E85 sold by CITGO in Dumfries, VA (per Shirley Ball, Executive Director of Ethanol Producers and Consumers [EPAC]). This price includes government subsidies of $\$ 0.54 /$ gallon of pure ethanol, or $\$ .08 /$ gallon of E85 (GAO/RCED-00-301R Tax Incentives for Petroleum and Ethanol Fuels, Sept. 2000).
} 


\section{Demonstration of Decision Support Tools for Sustainable Development}

The following test cases were derived and scoped for the initial demonstration. All test cases were compared to a baseline of no external influences to increase AF vehicle usage (i.e., no incentives or mandates). The test cases only considered non-stationary uses for the alternative fuels. Future analysis should also reflect the impacts on market growth from stationary uses of AF including electricity generation, heating and cooling, and industrial uses (including cogeneration).

\section{Test Case \#1}

Description: What are the net environmental and economic impacts of investing in CNG fleets in the Grand Teton National Park/Jackson/Teton County by 2020?

Input Assumptions: The National Park Service is mandated to increase the percentage of Alternative Fuel vehicles in their fleet to $10 \%$ by the year 2004. It is assumed that the mandates will cease at the end of 2004 and that the NPS will continue to supplement their fleets with alternative fueled vehicles driven by only by the market. There are no other incentives or mandates offered during this period. What is assumed is that the increase in demand for alternative fuel will be high enough to maintain itself at a sustainable level.

Results: The vehicle chart (Figure 5) shows an increase in AF use during the 4 year period of the government mandates but that the growth is not sustained after the mandates. In fact, after 25 years the mandates have very little effect on the overall total number of alternative vehicles in use.

\section{Figure 5. Test Case 1, Number of Vehicles}

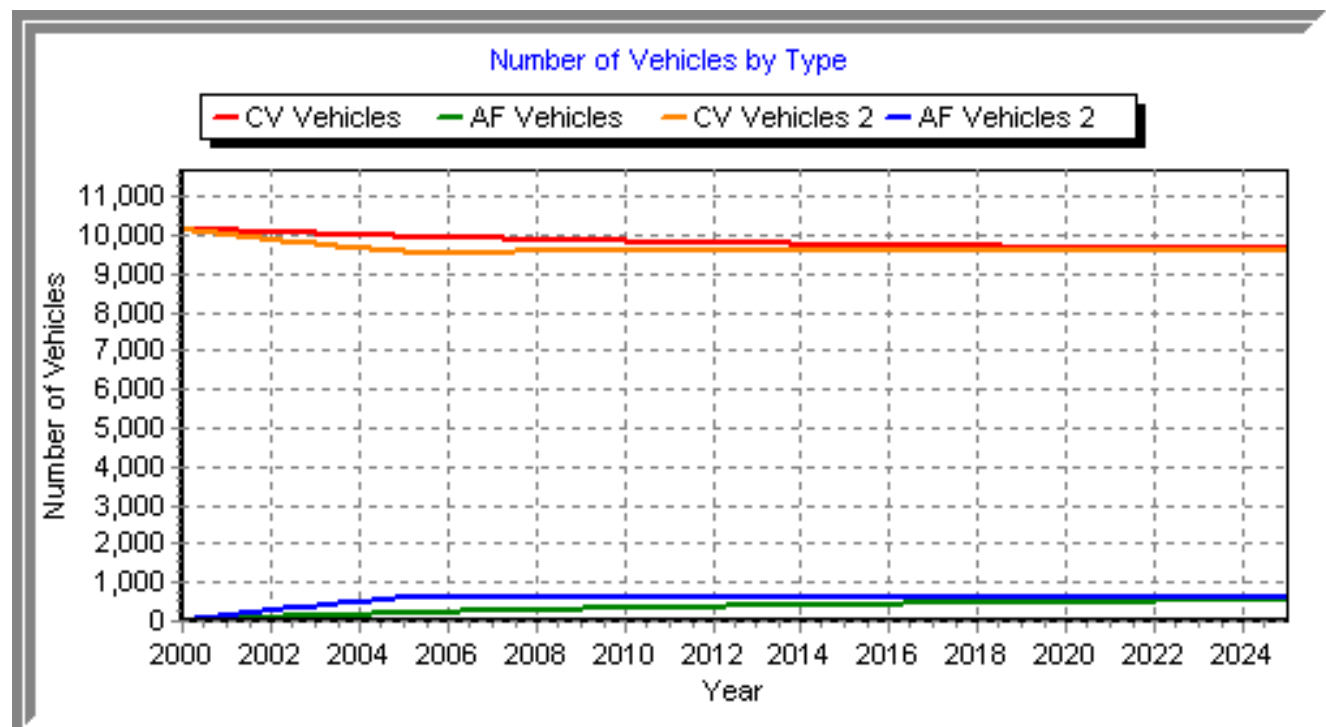

The emissions chart (Figure 6) shows a total decrease in emissions. It also shows a decrease in emissions from conventional fuels. This is not because conventional automobiles are becoming "greener" but due to the fact that conventional autos are being replaced with alternative fueled vehicles, therefore, there are simply fewer conventional fuel vehicles. So by replacing conventional fueled vehicles there is a positive environmental effect. 


\section{Demonstration of Decision Support Tools for Sustainable Development}

Figure 6. Test Case 1, Emissions

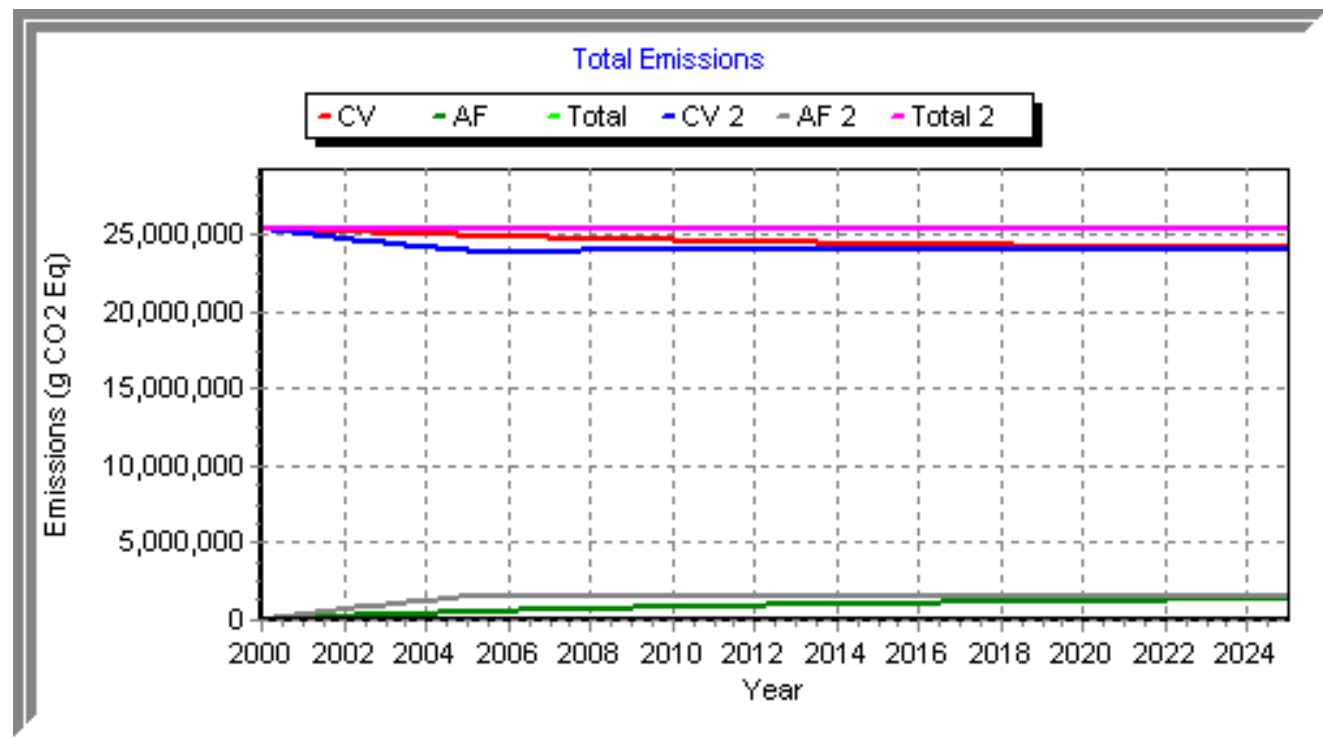

\section{Test Case \#2}

Description: What level of ethanol use in Yellowstone National Park/Montana would be required to make ethanol economically competitive with gasoline?

Input Assumptions: It is assumed that if demand for ethanol can be increased significantly, then producers of ethanol would be able to produce ethanol at a cheaper rate (economy of scale). If the price for ethanol were competitive with conventional fuel then it would be a viable alternative to conventional fuel. To test this theory, we incorporated a mandate that requires $20 \%$ of the fleets to be changed over to alternative fuel vehicles by the end of 2004. We assumed that the increased demand would decrease the price of ethanol and make the alternative fuel competitive with conventional fuel.

Results: The results from the vehicle chart (Figure 7) show that the number of alternative vehicles on the road increases rapidly over the first four years and then levels off at about 2,000 vehicles. The growth trend is accelerated by the mandate, but is not sustained after the mandates are removed. The base case shows steady growth toward achieving 2,000 vehicles over 25 years. 


\section{Demonstration of Decision Support Tools for Sustainable Development}

Figure 7. Test Case 2, Number of Vehicles

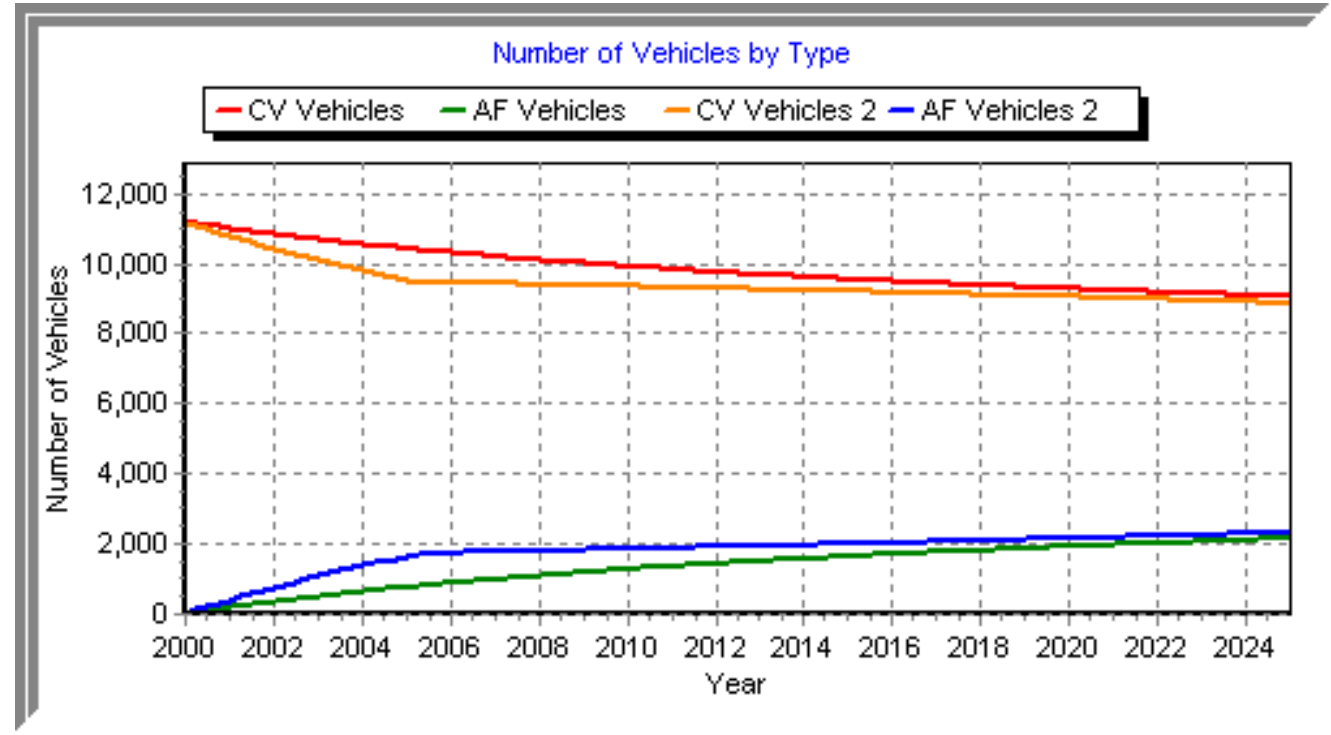

The economic impact chart (Figure 8) shows that the economic impact of the ethanol market is steadily increasing for primary industries but that the impact is minimal for secondary upstream industries. Secondary upstream industries are those industries that supply inputs to the primary industries such as wheat or feedstock corn for ethanol production. This point is supplemented by the results in the employment chart (Figure 9) which shows low employment numbers for both primary industries as well as secondary industries.

Figure 8. Test Case 2, Economic Impact

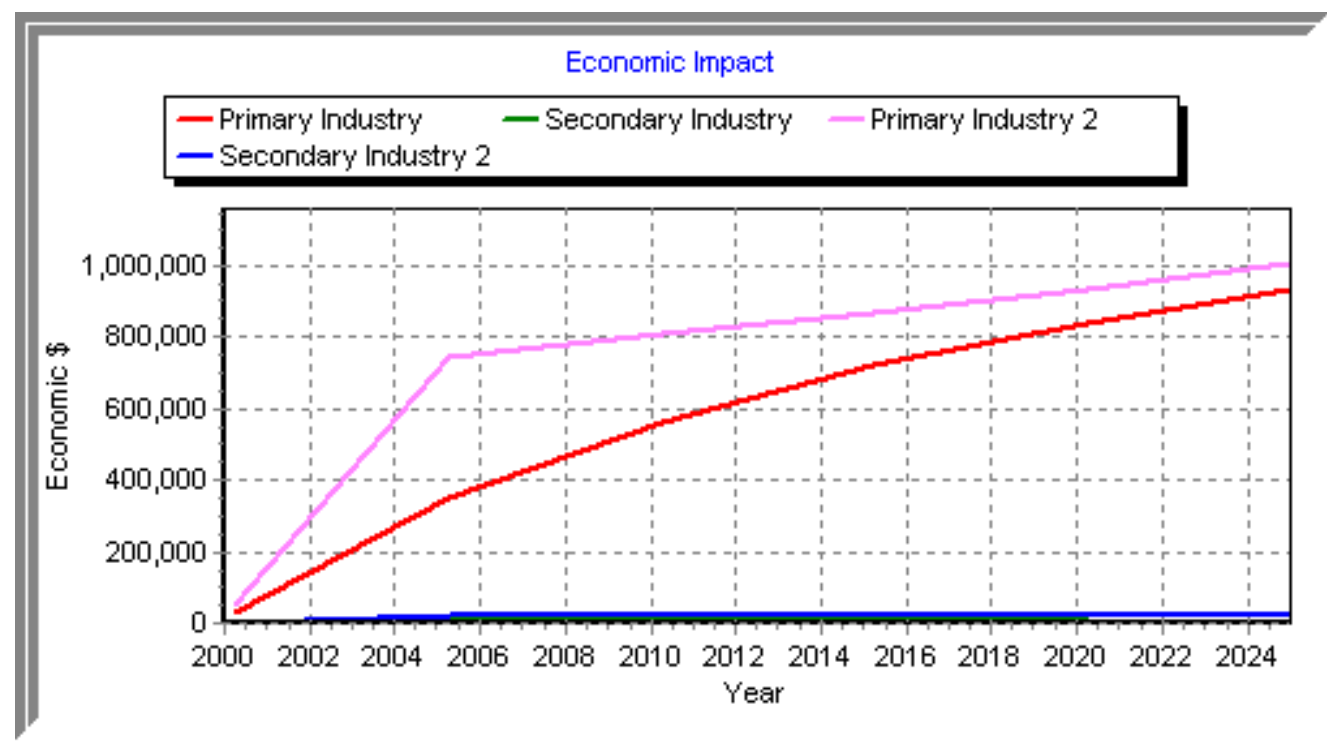




\section{Demonstration of Decision Support Tools for Sustainable Development}

Figure 9. Test Case 2, Employment Totals

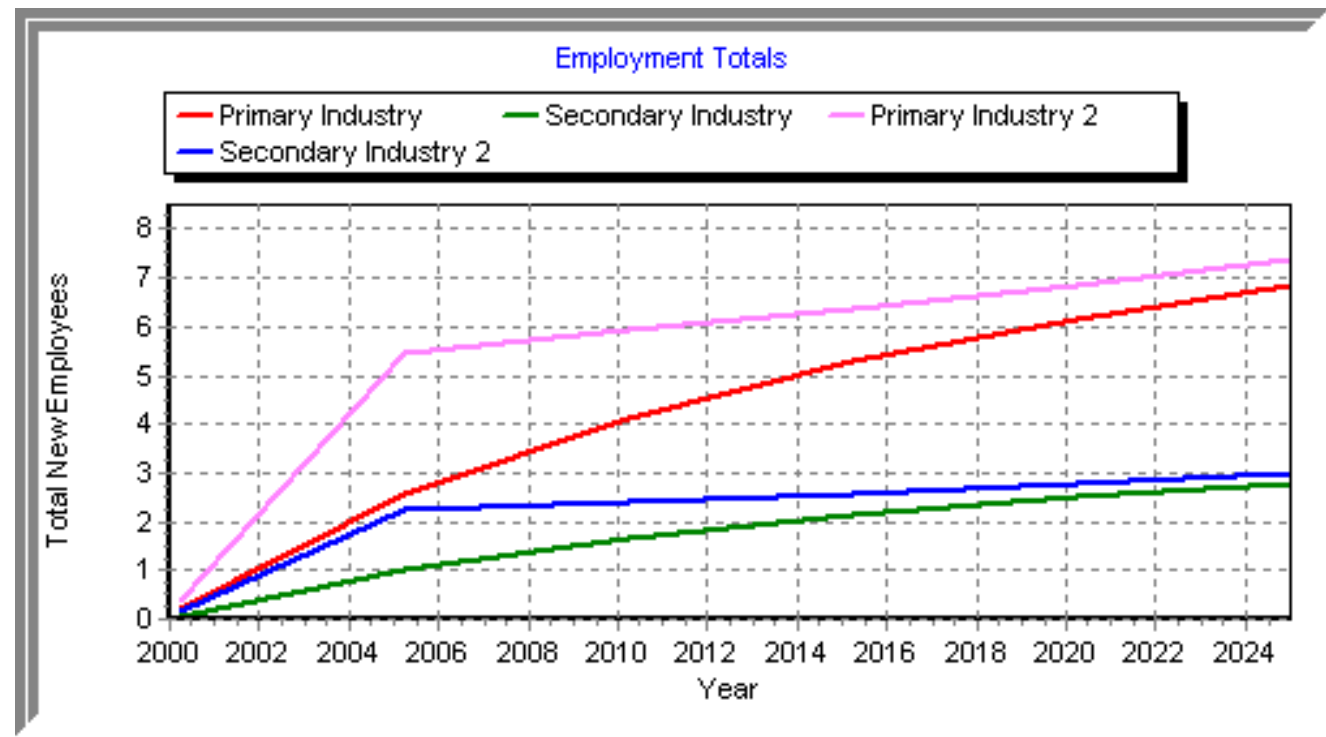

Also of note is the environmental chart (Figure 10) which shows a decreasing trend in overall emissions. In each of these runs, zero growth in population is assumed just to keep from confounding the results with too many changing parameters. Therefore the decrease in emissions would provide an environmental benefit.

Figure 10. Test Case 2, Total Emissions

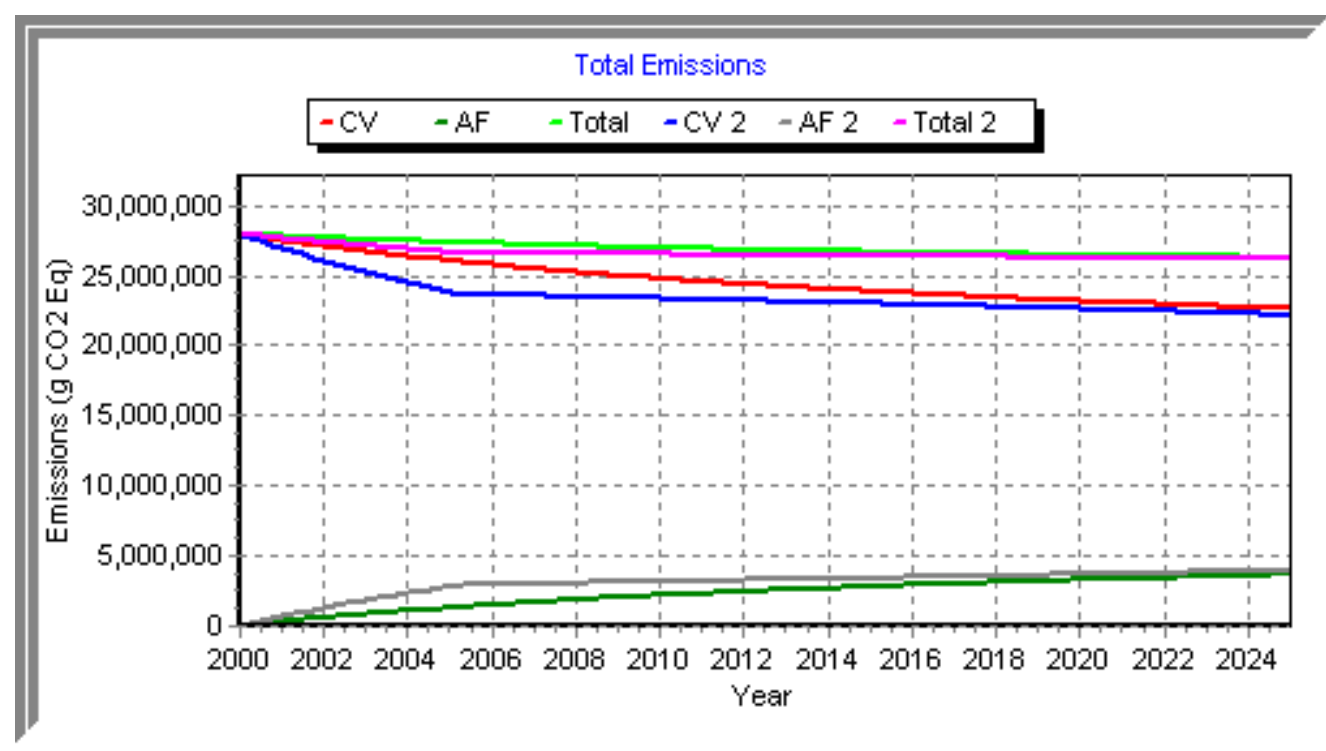




\section{Demonstration of Decision Support Tools for Sustainable Development}

\section{Test Case \#3}

Description: What secondary industries can be associated with ethanol production in Yellowstone National Park/Montana?

Input Assumptions. The low population in the GYT region may be insufficient to create a demand for ethanol as a fuel sufficient to develop production and distribution facilities locally. Other businesses that use ethanol would increase the demand and incentive to provide local supplies. IMEP helps identify potential new primary industries using ethanol, as well as secondary industries that supply materials needed to produce ethanol.

Results: Previous to creation of the GYT region scenario, a number of new industry input/output profiles associated with AF production and use were created and entered into the database to ensure that sufficient business profiles were available for a satisfactory demonstration of the combined models. These new AF profiles were prepared from a combination of real data obtained from various literature and Internet sources, realistic estimates prepared from conversations with people in the trade, and from professional judgement. IMEP will then select from both these new profiles and any other appropriate profile previously residing in the database.

The integrated models working together as DIME identified a total of 28 businesses potentially linked in AF production and use. These are presented on the screen as depicted in Figures 11 and 12. Complete results are presented in Table 1, Appendix A. Primary industries (Figure 11) are those producing or using ethanol directly. Secondary industries (Figure 12) are those producing a commodity used in ethanol production. Types of enterprises selected from the database are in two categories: real profiles obtained from available company information (e.g., "Ethanol: Cargill Corp."; "State of Montana, wheat production") and "generic" profiles created from published or estimated data (e.g., "Farm, winter wheat, Idaho, generic"; "Ethanol, corn, wet process"). "Real" companies listed in the AF scenario can serve either as potential opportunity for the company named, or for a newly created company with a similar profile of inputs and outputs. Generic companies in the AF scenario represent potential opportunities for the creation of new businesses. 


\section{Demonstration of Decision Support Tools for Sustainable Development}

Figure 11. Test Case 3, Primary Industries

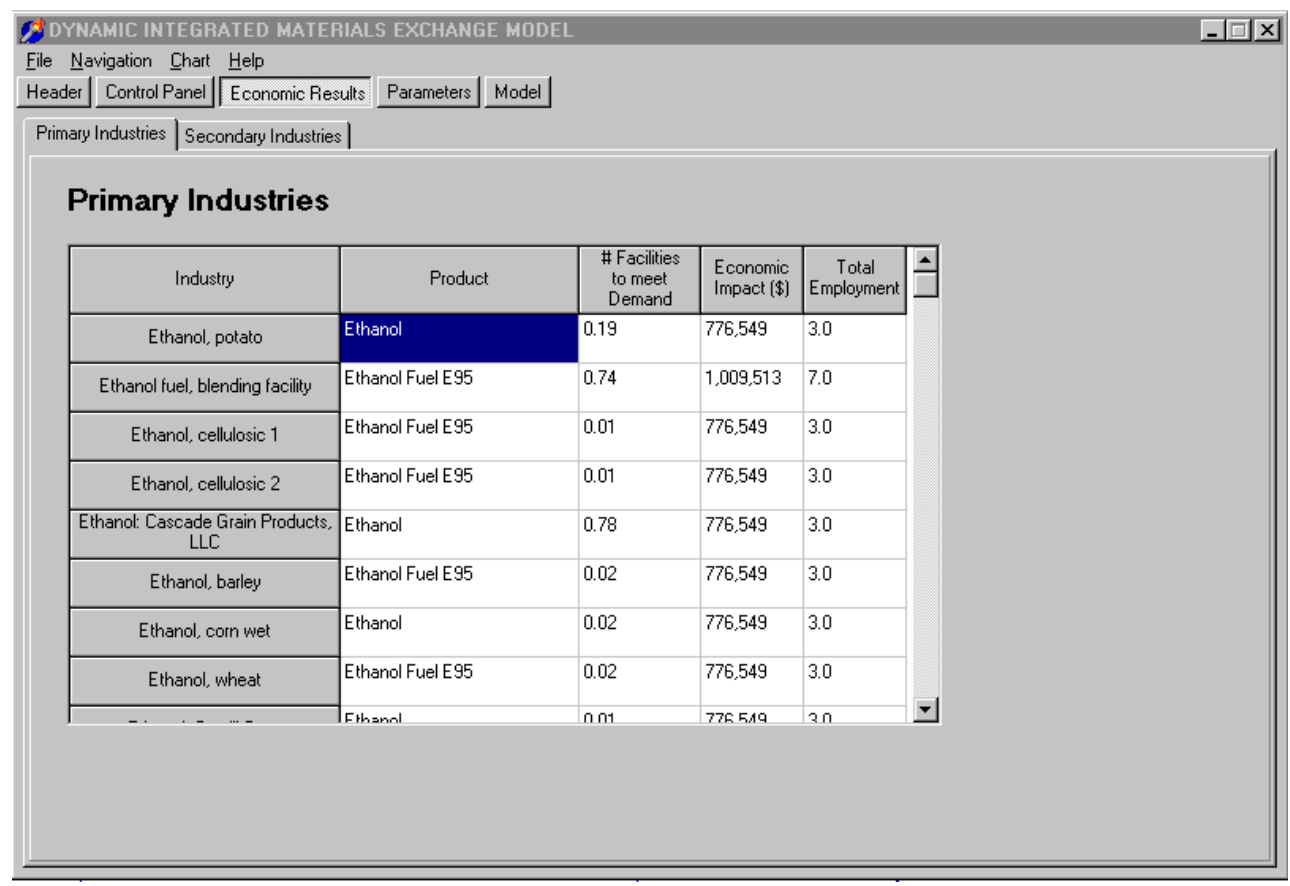

Figure 12. Test Case 3, Secondary Industries

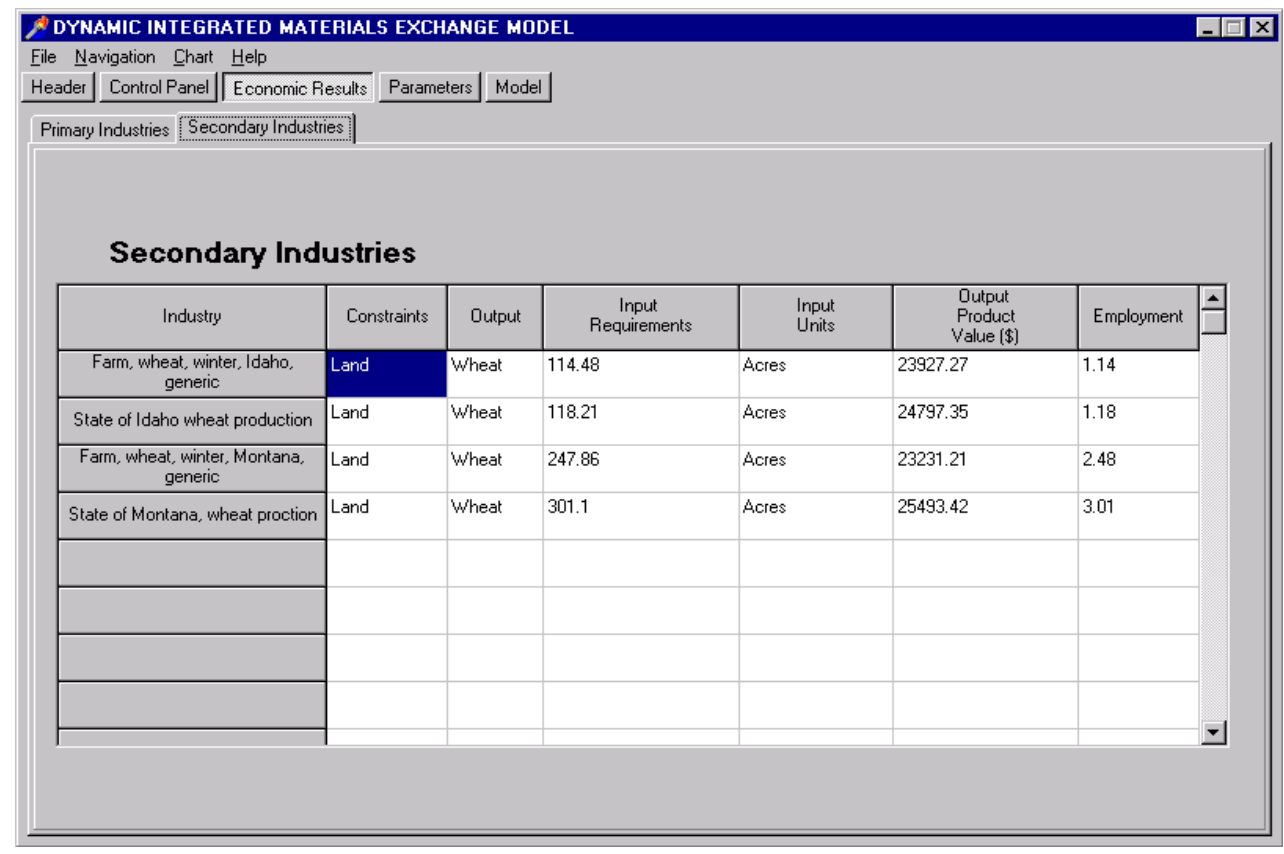




\section{Demonstration of Decision Support Tools for Sustainable Development}

The 28 linked potential industries represent the complete list of ethanol providers. For the CFRD demonstration, each supplies a small portion of the GYT regional ethanol requirement. Realistically, only one or a few producers of ethanol would be supplying this commodity. In the active project design process, the most feasible producers would be selected by the project planners and the remaining candidates removed from further consideration.

The 28 businesses were linked by the exchange of 49 materials streams. These are categorized as materials streams entering the region as feedstocks (or land required) needed by the companies in the scenario (Appendix A, Table 2); materials produced and exchanged among scenario companies within the region (Appendix A, Table 3); and products, by-products, or wastes that could either leave the region or be available locally for other businesses not yet linked to the AF Scenario (Appendix A, Table 4).

Modeling Sensitivities: IMEP is sensitive to input costs and market values of outputs of products, byproducts, and wastes. Sensitivity analysis is planned for future applications on IMEP but was not carried out for this demonstration.

\section{VALIDATION OF MODEL}

Review and recommendations on the modeling assumptions and design, including the market growth and utility functions (details provided in Appendix B) were provided by INEEL reviewers, university collaborators, and National Renewable Energy Laboratory (NREL). The model review process consisted of reviewing the Technical Requirements Document (Shropshire, September 2000); demonstrating the DIME model; verifying system behavior under extreme input parameter conditions; "sanity checking" results; reviewing the system dynamics stock and flow and causal relationships; and reviewing the reference basis and assumptions of the AF market growth utility functions. The feedback received from reviewers was incorporated into the design of the system or identified for possible future implementation.

Comments from external reviewers were documented in letters from Richard Parish (NREL, Golden Colorado) and Alicia Birky (NREL, Washington DC). Responses to the comments are documented in a letter from D. A. Cobb to Mr. Parish. The letters are provided in Appendix E.

\section{CONCLUSIONS AND RECOMMENDATIONS}

The integration of the IMEP and SD tools was successfully demonstrated on test cases involving the evaluation of alternative fuels in the Greater Yellowstone Teton region. With further development, the system could also be used to assist decision-makers (local government, planners, vehicle purchasers, and fuel suppliers) in selecting alternative fuels, vehicles, and developing AF infrastructures. The DIME system could become a regional AF market assessment tool that could help decision-makers understand the behavior of the AF market and conditions in which the market would grow. Based on this high level market assessment, investors and decision-makers would become more knowledgeable of the AF market opportunity before developing detailed plans and preparing financial analysis. 


\section{Demonstration of Decision Support Tools for Sustainable Development}

Future development activities are based on the feedback from INEEL Executive Management, the GYT Systems Program, and NREL reviewers. The recommendations are as follows:

1. Validation on "Real World" Data: Perform additional model validation and application on real data. We would work closely with NREL to validate, test, and improve the utility functions and AFs assessment capabilities. We would also work with Washington State University and MIT to review and validate the market growth functionality. After the reviews and required system updates are completed, we will test the system using the historical market growth for ethanol (corn based) in the Midwest. This validation process will increase confidence and visibility (through publications) in the model.

2. Addition of GIS Capabilities: Display of GIS data is a very desirable capability for future decision systems. The DIME database has been designed to include GIS data, but the interfaces need to be developed to display and output this information. Geographical information on industrial material sources can be identified and Global Positioning System coordinates could be provided for business locations.

3. Additional Recommendations for Future Development: Future development could include applying the system to higher population density regions; accounting for seasonal fluctuations; providing detailed AF infrastructure requirements; expanding to other types of AF vehicles (flex fuel and blends), and assessing environmental, economic, or socio-economic "net" benefits and costs including impacts on (or from) system externalities; and further development of the fuel life-cycle assessment capabilities.

\section{ACKNOWLEDGEMENTS}

We acknowledge the support provided by Richard Parish and Alicia Birky from NREL for the review of the project requirements, methodology and models. We also acknowledge the thoughtful review and insights provided by John Beller, Basil Barna, and Bob Nitschke from the INEEL Greater Yellowstone Teton Systems Program.

\section{REFERENCES}

1. Work for Others (WFO) Project No. 00830, Package (CFRD) BNI-0005-03, June 22, 2000.

2. INEEL Strategic Plan, Draft - Rev. 5, July 11, 2000.

3. B. Barna, Greater Yellowstone - Teton Systems Analysis presentation, July 18, 2000.

4. Greater Yellowstone/Teton Clean Cities Coalition, Market Development \& Clean Cities Action Plan, April 2000.

5. Shropshire, D.E., et al, Technical Requirements Document, Sustainability Modeling for the National Park System, INEEL/EXT-2000-01077, September 2000. 


\section{Demonstration of Decision Support Tools for Sustainable Development}

\section{APPENDICES}

\section{Appendix A-Industrial Material Exchange Model Description}

Bechtel and Nexant have developed and are applying a set of tools and methodologies to help companies, industrial regions and countries define and achieve goals for sustainable industrial development. The Industrial Materials Exchange Planner (IMEP), a proprietary Bechtel/Nexant software tool, is an integrated platform for technical and economic analysis of the exchange of materials, wastes, and energy within or among industrial/economic regions, industrial complexes, and companies. Industrial systems can be designed and planned to improve profitability and resource efficiency, to eliminate waste and reduce environmental impacts, and to identify business opportunities that offer positive economic and environmental synergies

IMEP is a comprehensive tool for planning new industrial projects as well as for improving the operation of existing industrial complexes. For new industrial projects, the best clusters of complementary firms measured on both economic and environmental scales - can be identified. Alternative model scenarios based upon production levels, feedstock costs, waste and by-product generation, disposal and treatment cost, and transportation costs can be considered, and investment decisions for waste reprocessing capability and complementary secondary and tertiary industries can be analyzed. For existing industrial projects, a comprehensive assessment of materials and energy flows can be carried out in order to identify opportunities for improving resource efficiency, reducing unproductive waste generation and increasing profitability.

The IMEP is composed of a technology database of over 300 primary industrial processes as well as recycling and reprocessing operations, and a set of powerful scenario development and optimization tools for evaluating alternative IMEP configurations. Given material inputs, by-products, wastes, and energy use, complementary industries and technically feasible recycling operations are identified from the technology database. The optimization tools are used to determine the best exchange opportunities based upon the costs of material inputs, waste treatment or disposal, reprocessing, and transportation.

IMEP was applied to the model database to determine the companies that could link potentially in a GYT region ethanol and CNG production and use exchange scenario ("AF Scenario"). The primary output from IMEP to the Systems Dynamics model is the total economic impact for each alternative fuel demand scenario, as measured by total revenue associated with the sale of all primary and secondary products in the system, and the capacity constraints for production of that fuel as measured by the number of required facilities or the amount of land required to produce the agricultural inputs. For each time step in the forecasting horizon, the SD model sends a specified fuel demand to IMEP. IMEP then returns company profiles for all primary fuel producers in the IMEP database (product value and number of facilities), all upstream product suppliers (product value and number of facilities or amount of land), and all downstream product consumers (product value and the quantity of product produced per unit input available ethanol, for example) in the system.

IMEP identified 28 businesses potentially linked in AF production and use. The lists below are presented as a demonstration for this CFRD project only. The focus of the CFRD was on production and use of AF, and by far the largest proposed use for ethanol was as a fuel. There are other commercial uses for ethanol, but relatively few were present in the existing IMEP database (e.g., perfume, medicinal tinctures, and flavorings). Thus, IMEP did not draw them into the AF Scenario, nor were they a part of the overall DIME analysis. If this planning process is used in the GYT region in the future, many more non-fuel use 


\section{Demonstration of Decision Support Tools for Sustainable Development}

profiles will be required to form a realistic picture of the potential for additional regional non-fuel ethanol use in the future.

Other potential uses for ethanol include: soaps and other cleansers, lotions, solvents and thinners, preservatives, sterilizing solutions, edible coatings, dyes, inks, stains, blending agents and extenders, beverages, photographic chemicals, and gasoline oxidants (replacing MBTE). Adding IMEP profiles for these additional industries will greatly expand the range of ethanol uses as well as products, byproducts, and potentially recyclable wastes available in the AF Scenario region. It is assumed that CNG would be used as a fuel only.

Table 1. Potentially GYT regional commercial enterprises linked to ethanol production and usage.

\begin{tabular}{|c|c|c|c|}
\hline Company name & Com & Processes & Description \\
\hline ARKENOL - Ethanol & $\mathrm{VOH}$ & Concentrated acid hydrolysis; Ethanol and other & Primary Ethanol \\
\hline Ethanol fuel, blending facility & V00 & Generic & Primary Ethanol \\
\hline Ethanol fuel, dispensing facility & V01 & Generic & Secondary Ethanol \\
\hline Ethanol, barley & V09 & Ethanol from barley; dry milling & Primary Ethanol \\
\hline Ethanol, cellulosic 1 & V05 & Biomass to ethanol fuel (E95) & Primary Ethanol \\
\hline Ethanol, cellulosic 2 & V06 & Transesterification. & Primary Ethanol \\
\hline Ethanol, corn wet & V0B & Wet milling. Comment: Typical ethanol yield from & Primary Ethanol \\
\hline Ethanol, potato & 140 & Dry milling.Reference: American Coalition for & Primary Ethanol \\
\hline Ethanol, wheat & V0D & Dry milling. & Primary Ethanol \\
\hline Ethanol: Ag Processing, Inc. & V0R & Dry milling of corn \& milo & Primary Ethanol \\
\hline Ethanol: Cargill Corp. & VOF & Wet milling & Primary Ethanol \\
\hline Ethanol: Cascade Grain Products, LLC & V08 & Ethanol from corn and wheat & Primary Ethanol \\
\hline Ethanol: Chief Ethanol Fuels & V0Q & Dry milling of corn & Primary Ethanol \\
\hline Ethanol: High Plains Corporation & $\mathrm{V} 0 \mathrm{O}$ & Dry milling & Primary Ethanol \\
\hline Ethanol: Minnesota Corn Processors & V0M & Wet milling of corn & Primary Ethanol \\
\hline Ethanol: Nebraska Energy, LLC & V0P & Dry milling & Primary Ethanol \\
\hline Ethanol: Sutherland Associates & V0S & Dry milling & Primary Ethanol \\
\hline Farm, rapeseed and oil & V02 & Generic profile - estimated values & Secondary Ethanol \\
\hline Farm, wheat, winter, Idaho, generic & V0I & Farming & Secondary Ethanol \\
\hline Farm, wheat, winter, Montana, generic & V0K & Farming & Secondary Ethanol \\
\hline Flavoring extracts, culinary & V07 & Generic profile as place holder & Secondary Ethanol \\
\hline Gas, compressed natural & V03 & Generic Profile & Primary CNG \\
\hline Medicinals, tincture of iodine, generic & V0C & Generic profile as place holder & Secondary Ethanol \\
\hline Perfume, generic & V04 & Generic profile as place-holder & Secondary Ethanol \\
\hline Solvent, ethanol & V0A & Generic profile as place holder & Secondary Ethanol \\
\hline State of Idaho wheat production & V0J & Farm production & Secondary Ethanol \\
\hline State of Montana, wheat production & VOL & Farm production & Secondary Ethanol \\
\hline Vodka beverage plant & V0E & Generic profile as place holder & Secondary Ethanol \\
\hline
\end{tabular}

These 28 companies in the AF Scenario were linked by 49 potential materials exchanges, presented in Table 2, Materials Entering the GYT Region (27 materials); Table 3, Materials Exchanged within the GYT Region (4); and Table 4, Materials Leaving the GYT Region (18). 
Table 2. Materials entering the Ethanol Scenario.

\begin{tabular}{|l|l|}
\hline Com_id & \multicolumn{1}{|c|}{ Name } \\
\hline AA1 & Sulfuric Acid \\
\hline B07 & Lime \\
\hline E01 & Enzymes, hydrolysis \\
\hline E04 & Neutralizer \\
\hline E07 & Barley \\
\hline E08 & Enzyme, dextrase \\
\hline E0A & Enzyme, undetermined \\
\hline E0D & Enzyme, alpha-amylas \\
\hline E0E & Enzyme, gluco-amylas \\
\hline F41 & Gasoline \\
\hline GB3 & Packaging \\
\hline K02 & Water-potable \\
\hline L01 & Plastic containers, \\
\hline L02 & Iodine crystals \\
\hline N0B & Corn \\
\hline N0C & Potatoes \\
\hline Q0A & Trees, Cottonwood \\
\hline Q0B & Trees, Red Alder \\
\hline Q0C & Grass, switchgrass \\
\hline Q0D & Grass, wheatgrass \\
\hline Q0K & Rice straw \\
\hline Q16 & Herbicides \\
\hline T03 & Land \\
\hline T04 & Fertilizer, nitrogen \\
\hline T05 & Fertilizer, potassium \\
\hline T06 & Fertilizer, phosphor \\
\hline T0B & Milo \\
\hline & \\
\hline
\end{tabular}

Table 3. Materials exchanged within the Ethanol Scenario

\begin{tabular}{|l|l|}
\hline Com_id & \multicolumn{2}{|c|}{ Name } \\
\hline E61 & Ethanol \\
\hline N00 & Yeast \\
\hline N0K & Wheat \\
\hline N0L & Wheat \\
\hline
\end{tabular}




\section{Demonstration of Decision Support Tools for Sustainable Development}

Table 4. Materials leaving the Ethanol Scenario as product, by-product, or waste.

\begin{tabular}{|l|l|}
\hline Com_id & \multicolumn{1}{c|}{ Name } \\
\hline C31 & Gypsum \\
\hline E00 & Ethanol Fuel E95 \\
\hline E0C & Starch, industrial \\
\hline E0G & Lignin \\
\hline E24 & Protein \\
\hline E53 & Ethane \\
\hline L03 & Medicinal, tincture \\
\hline N0F & Sweetener \\
\hline N0G & Starch, corn \\
\hline N0H & Oil, vegetable \\
\hline N0I & Grain, distillers \\
\hline N0J & Syrup, distillers \\
\hline Q0E & Feed, animal \\
\hline Q0G & Fiber, germ \\
\hline Q0J & Corn, milling fiber \\
\hline Q15 & Fiber, agricultural, \\
\hline R11 & Carbon Dioxide \\
\hline S00 & Ash \\
\hline
\end{tabular}




\section{Appendix B-System Dynamics Model Description}

High Level Causal Relationships

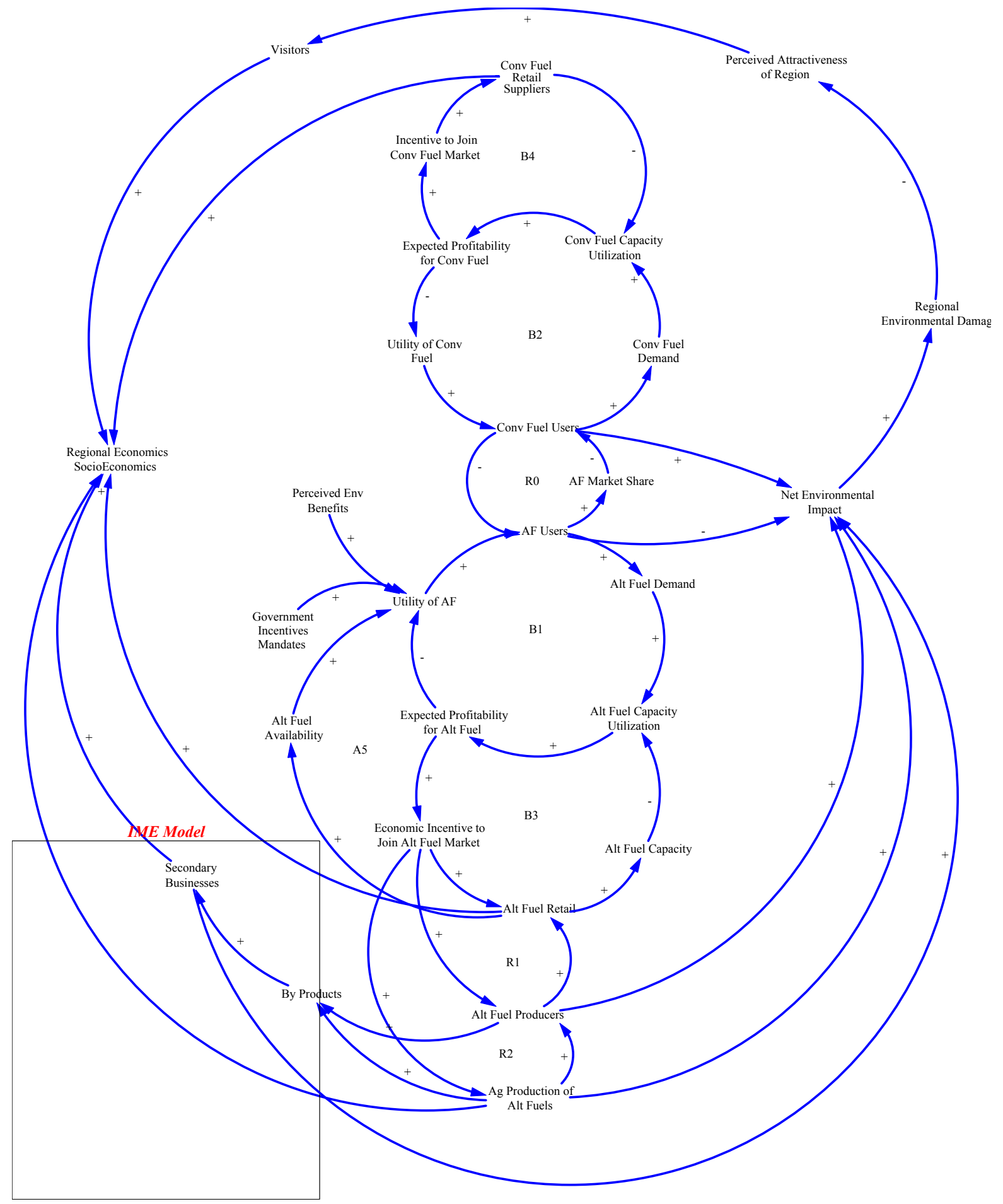




\section{Demonstration of Decision Support Tools for Sustainable Development}

\section{Market Growth Model}

The market growth model contains two components of that represent the basic structure that would influence the market growth of a commodity, in this case, alternative fuel. Those two components are "Order Fulfillment" and "Capacity Acquisition". The combination of these two components strongly influence the behavior of the customers and hence their demands for the product. Long delivery delays and shortages will drive customers to other substitution products. On the other hand, low costs and easy acquisition will draw customers to the market.

The two components also strongly influence each other. Too much supply would drive the price of the commodity down which effects profits. Low profits generally drive the producers to produce less. Less production drives supply down, which eventually drives the price back up. However, the inherent delays, recognition of low profits, backlog, high inventories, in the system usually cause a self-inflicted oscillation of price, supply and production. Furthermore, large oscillations would cause for over capacity buildup as well as severe layoffs.

Using the model, managers can become aware how their behaviors are actually causing the oscillations that they are trying to avoid. Performing gaming, or what if, scenarios on capacity increases, commodity pricing, inventory coverage and supply times allows the managers to experiment with different management strategies and receive real time feedback of the consequences.

\section{Model Parameters and Assumptions}

\begin{tabular}{|l|l|l|l|}
\hline No & Parameter & Value & Units \\
\hline 1 & Capital Productivity & 1 & Units/Year/Capital Unit \\
\hline 2 & Average Life of Capacity & 20 & Years \\
\hline 3 & Capacity Acquisition Delay & 4 & Years \\
\hline 4 & Capacity Adjustment Time & 3 & Years \\
\hline 5 & Supply Line Adjustment Time & 1 & Year \\
\hline 6 & Time to Adjust Long-Run Price Expectations & 2 & Years \\
\hline 7 & Reference Inventory Coverage & 0.2 & Years \\
\hline 8 & Minimum Order Processing Time & 0.1 & Years \\
\hline 9 & Manufacturing Cycle Time & 0.5 & Years \\
\hline 10 & Utilization Adjustment Time & 0.5 & Years \\
\hline
\end{tabular}




\section{Demonstration of Decision Support Tools for Sustainable Development}

\begin{tabular}{|l|l|l|l|}
\hline 11 & Time to Adjust Short-Run Price Expectations & 1 & Year \\
\hline 12 & Initial Variable Cost Fraction & 0.4 & Dmnl \\
\hline 13 & Reference Industry Demand Elasticity & 0.5 & Dmnl \\
\hline 14 & Demand Adjustment Delay & 0.5 & Years \\
\hline 15 & Maximum Consumption & $1 \mathrm{e} 8$ & Units/Year \\
\hline 16 & Sensitivity of Price to Inventory Coverage & -1 & Dmnl \\
\hline 17 & Coverage Perception Time & 0.167 & Years \\
\hline 18 & Sensitivity of Price to Costs & 1 & Dmnl \\
\hline 19 & Time to Adjust Traders' Expected Price & 1 & Year \\
\hline 20 & Sensitivity of Investment to Exp Profit & 1 & Dmnl \\
\hline 21 & Initial AF Price (Ethanol - E85) & 250 & Cents \\
& Initial AF Price (CNG) & 165 & Cents \\
\hline 22 & CV Price & Varies & Dmnl \\
\hline 23 & Standard Emissions (Gasoline) & Cents \\
\hline 26 & Vehicle Efficiency & Varies & Miles/Gallon \\
\hline
\end{tabular}




\section{Demonstration of Decision Support Tools for Sustainable Development}

\section{Definitions of Parameters:}

1. Capital Productivity -- Units of product produced by one capital unit.

2. Average Life of Capacity - Average Life usage period before a facility or machine is retired.

3. Capacity Acquisition Delay - The time the elapses between when an increase in capacity is ordered and when it is put on-line.

4. Capacity Adjustment Time - The average time over which producers seek to close the gap between desired and actual capacity.

5. Supply Line Adjustment Time -The time period over which the supply line of capacity on order or under construction is adjusted to its goal.

6. Time to Adjust Long-Run Price Expectations - The amount of time to change expectations on long-term price expectations.

7. Reference Inventory Coverage - The amount of inventory coverage desired to cover the reference inventory (to set up initial conditions)

8. Minimum Order Processing Time - The time it takes to ship out a unit of product that is ready for shipment.

9. Manufacturing Cycle Time - Time to process a unit of product.

10. Utilization Adjustment Time - The time between the decision to increase production till the time that production actually increases.

11. Time to Adjust Short-Run Price Expectations - The amount of time to change expectations on short-term price expectations.

12. Initial Variable Cost Fraction - The initial cost of a product that is variable and can change. In technology and knowledge intensive industries involving significant product development effort, nearly all the costs are incurred prior to production of the first unit.

13. Reference Industry Demand Elasticity - the amount of change in demand with a change in price.

14. Demand Adjustment Delay -Industry demand adjusts to the indicated demand with a delay, representing the time required for consumers of the good to find substitutes or change their consumption after a change in price. This is the time it takes actual demand to change after there is a change in indicated demand.

15. Maximum Consumption - The most product that will be sold regardless of how low the price goes. 


\section{Demonstration of Decision Support Tools for Sustainable Development}

16. Sensitivity of Price to Inventory Coverage - Determines how fast price will adjust with changes in inventory coverage.

17. Coverage Perception Time - Time required to determine that there is a discrepancy between desired inventory coverage and actual inventory coverage.

18. Sensitivity of Price to Costs - Determines how fast price will adjust to changes in cost. If the Sensitivity of Price to Cost $=0$, then cost information is ignored in price setting. If Sensitivity of Price to Cost $=1$, then traders' beliefs about the equilibrium price are ignored and prices are anchored on expected costs instead.

19. Time to Adjust Expected Price - The time it takes to make changes in the expected price of a product when the actual price changes.

20. Sensitivity of Investment to Expected Profit -- The Sensitivity of Desired Capacity to expected profit.

21. Initial AF Price - the initial price of the alternative fuel at the beginning of the simulation.

22. CV Price - the price of conventional fuel during the simulation. Can only be changed manually not affected by model influences.

23. Standard Emissions - the average amount of emissions from conventional vehicles. All other types of vehicles are measured against this value.

24. Emissions Fraction - The fraction of the standard emissions of conventional vehicles that are emitted by alternative fuel vehicles.

25. Annual travel - The average number of miles that any type of vehicle travels each year. Assumed to be the same for every type of vehicle.

26. Vehicle Efficiency - The efficiency of the alternative vehicle types based on miles per equivalent gallon (mpeg). The mpeg measurement gives an estimate of how far the vehicle can travel on an amount of fuel that has the same energy content as a gallon of gasoline.

Assumptions:

1. Alternative Fuel will be competing directly with Conventional Fuel. The market in the area will be small relative to the entire conventional fuel market so it will not influence the price of conventional fuel.

2. The greater the capacity to produce alternative fuel, the lower the cost of producing a single unit of product.

3. The base price of vehicles, horsepower, emissions and driving range is constant throughout the simulation. Variations of these due to technology advances may change in future revisions of the program. 


\section{Demonstration of Decision Support Tools for Sustainable Development}

\section{System Dynamics Market Growth Utility Function}

The market share equations are adapted from a discrete-choice model published by researchers from the University of California. ${ }^{3}$ The array $\mathrm{U}$ stands for the utility of each vehicle type. Market shares are found by:

$$
\begin{aligned}
& \text { Market_shares }[\mathrm{V}]=\text { numerator }[\mathrm{V}] / \text { denominator } \\
& \text { Numerator }[\mathrm{V}]=\exp (\mathrm{U}[\mathrm{V}]) \\
& \text { Denominator } \left.=\text { ARRAYSUM(numerator }\left[{ }^{*}\right]\right)
\end{aligned}
$$

Which is equivalent of the multinomial logit equation commonly expressed as:

$$
M S v=e^{\wedge} U v / S U M\left(e^{\wedge} U i\right)
$$

The utility of each vehicle type is expressed as a sum of separate utilities on the six attributes:

$$
\begin{aligned}
& \mathrm{U}[\mathrm{V}]=\mathrm{U} 1[\mathrm{~V}]+\mathrm{U} 2[\mathrm{~V}]+\mathrm{U} 3[\mathrm{~V}]+\mathrm{U} 4[\mathrm{~V}]+\mathrm{U} 5[\mathrm{~V}]+\mathrm{U} 6[\mathrm{~V}] \\
& \mathrm{U} 1=\text { coef_1 } \\
& \mathrm{U} 2=\text { coef_2*fuel_cost[V] } \\
& \mathrm{U} 3=\text { coef_3A*(range[V]/100) }+ \text { coef_3B* }\left((\operatorname{range}[\mathrm{V}] / 100)^{\wedge} 2\right) \\
& \mathrm{U} 4=\text { coef_4A*emission_fr[V]+coef_4B*emission_fr[V }]^{\wedge} 2 \\
& \mathrm{U} 5=\text { coef_5A*fuel_availability[V]+coef_5B*fuel_availability[V }]^{\wedge} 2 \\
& \mathrm{U} 6=\text { coef_6*horse_power[V] }
\end{aligned}
$$

A single coefficient means that the utility is a linear function of the attribute. Two coefficients indicate that the utility is a nonlinear function of the attribute. The functions were determined from approximately seven hundred responses to a mail-back survey. The responders described their preferences for vehicles with different prices, fuel costs, ranges, etc. The researchers structured the statistical model to provide the best explanation of the stated preferences.

\footnotetext{
${ }^{3}$ Bunch, David; Bradley, Mark; Golob, Thomas; Kitamura; Ryuichi; and Occhiuzzo, Gareth. 1992. Demand for clean fuel personal vehicles in California: A discrete choice stated preference survey. March 20. Institute for Transportation studies, University of California, Irvine, CA 92717.
} 


\section{Demonstration of Decision Support Tools for Sustainable Development}

The best fit was found with the following coefficients:

$$
\begin{aligned}
& \text { Coef_1 }=-.143 \\
& \text { Coef_2 }=-.175 \\
& \text { Coef_3A }=2.06 \\
& \text { Coef_3B }=-.303 \\
& \text { Coef_4A }=-3.08 \\
& \text { Coef_4B }=1.53 \\
& \text { Coef_5A }=2.24 \\
& \text { Coef_5B }=-.956 \\
& \text { Coef_6 }=.00796
\end{aligned}
$$

Note that coefficients were developed for average of alternative fuels. In the future more precise coefficients can be used for specific alternative fuels. 


\section{Demonstration of Decision Support Tools for Sustainable Development}

\section{Appendix C—Database Interface Description}

A relational database was developed and used to store data on the project. A relational database management system gives the user access to the data and helps them transform the data into information. The database allows users to create, update, and extract information in methods appropriate for their immediate need.

An interface to the database was created to allow potential users access to the current database and to provide a tool for future data management. This also provides the user with a stand-alone tool for management of information related to park service activities. The following are screens from the standalone database system.

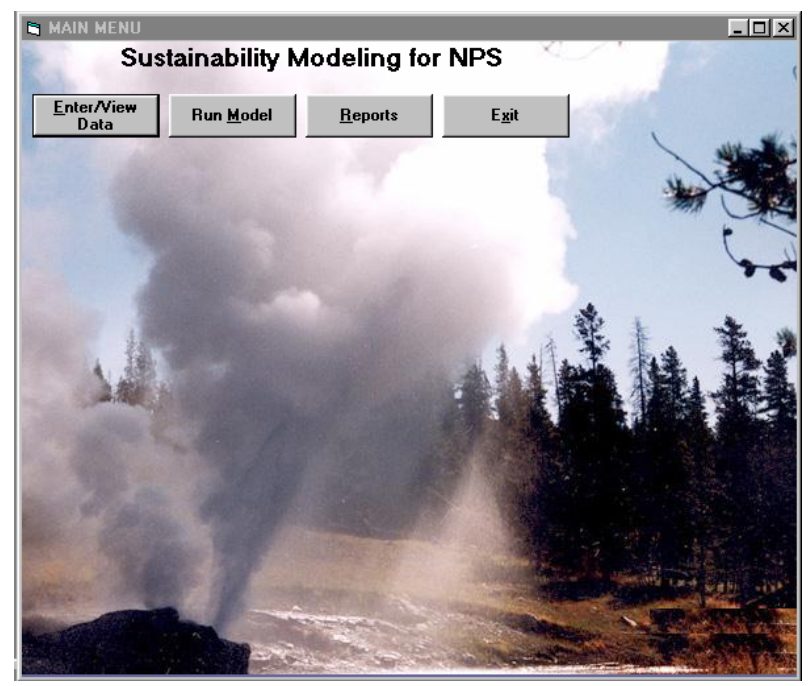

DIME database main menu. For ease of use the model can be launched from this menu.

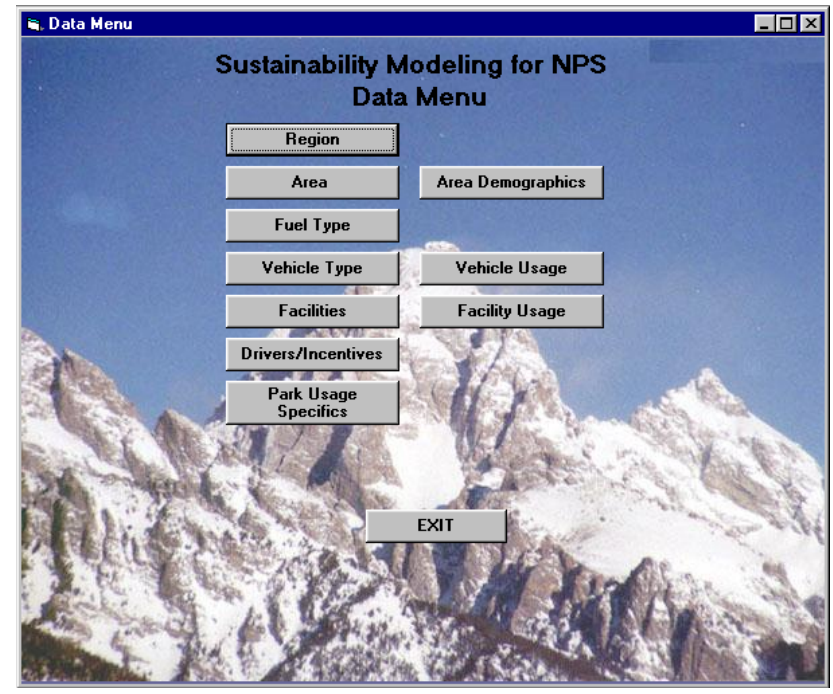

This is the main data menu that is displayed when Enter/View data is selected from the main menu. 


\section{Demonstration of Decision Support Tools for Sustainable Development}

From this menu you can select options to enter of view data about Region, Area, Demographics, Fuel Types, Vehicle Types and Usage, Facilities and Usage, Drivers and Incentives or Park Usage Specifics.

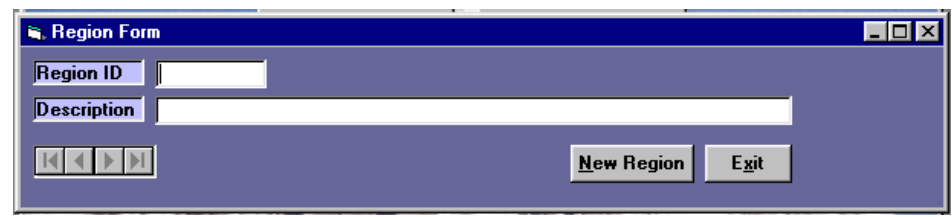

Used to enter or view region information.

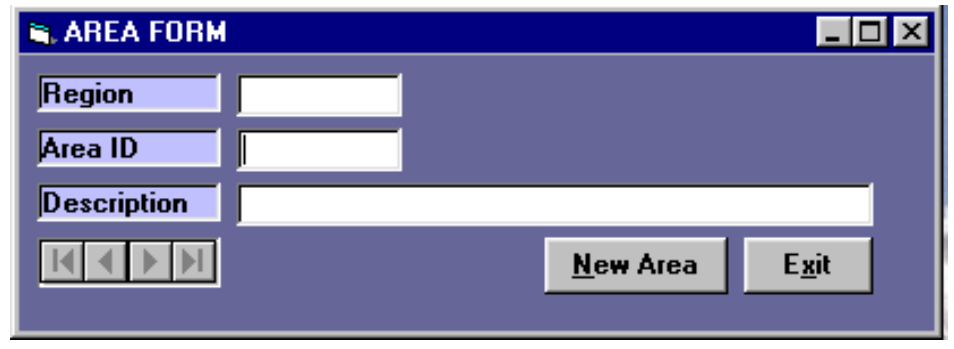

Used to enter or view area information.

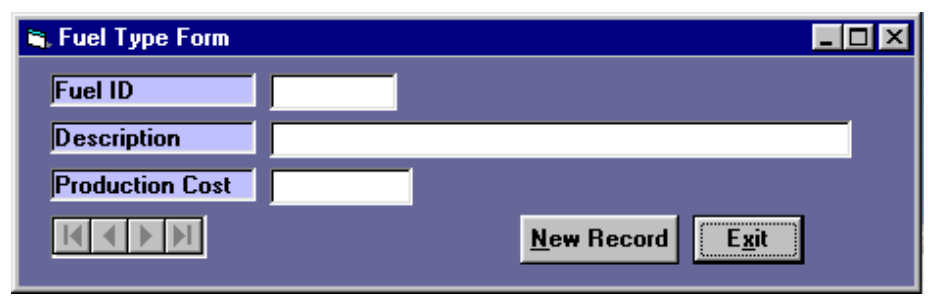

Used to enter or view fuel type information. 


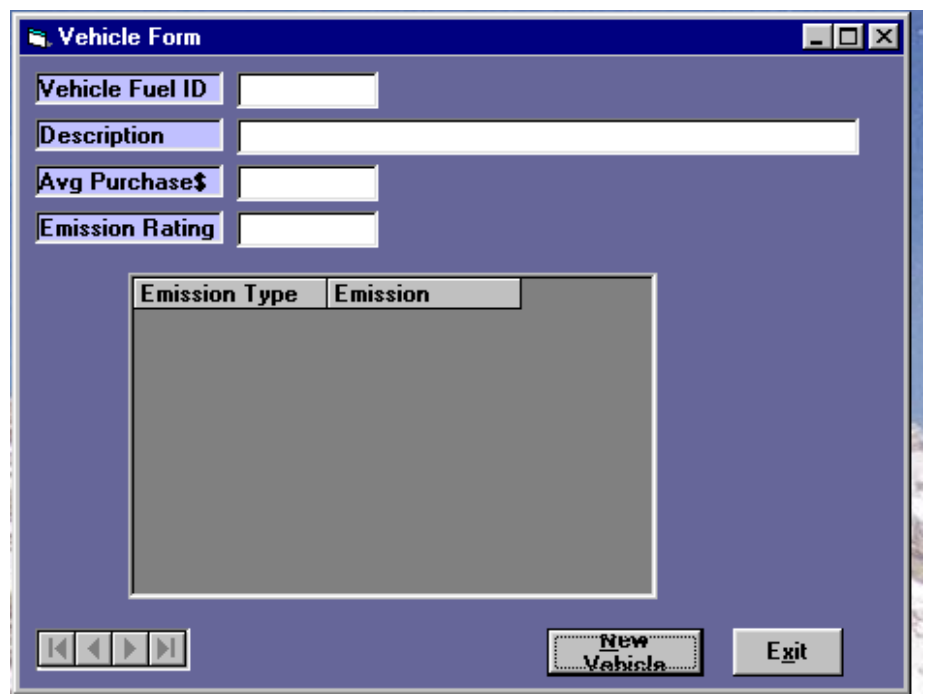

Used to enter or view vehicle information.

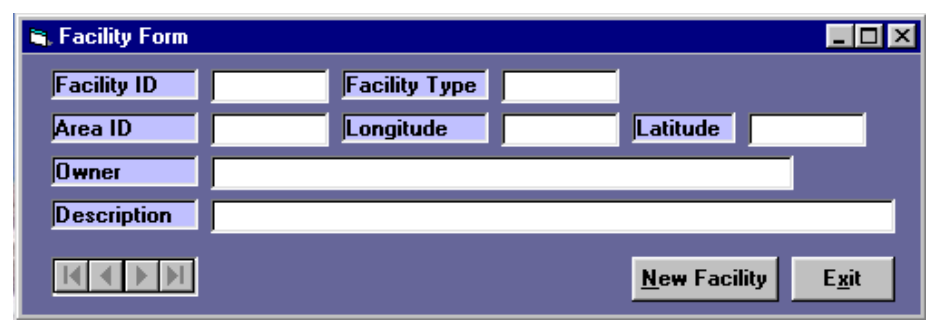

Used to enter or view facility data.

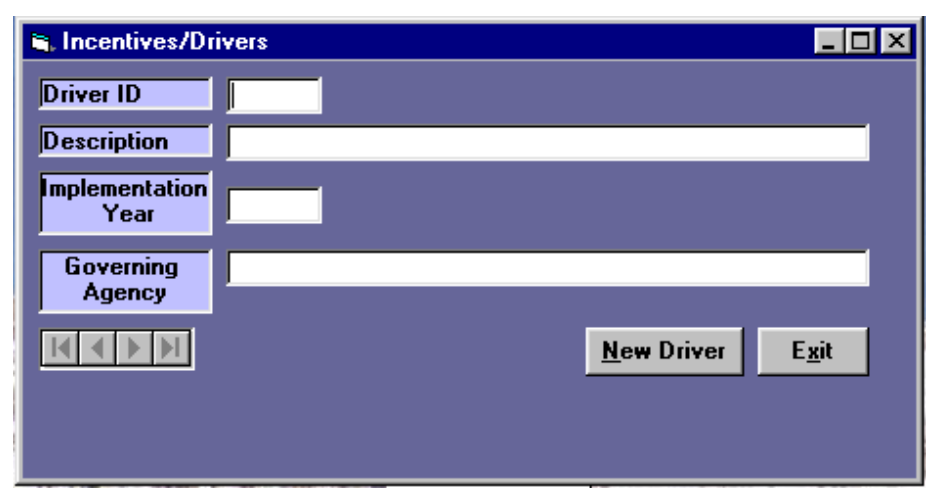

Used to enter or view incentive and driver data. 
Park Usage Specifics

\section{- $\square$ 口}

\begin{tabular}{|c|c|c|c|c|}
\hline \multicolumn{2}{|c|}{ Area ID } & & Year & \\
\hline \multicolumn{3}{|c|}{ \# Visitors } & \# Vehi & \\
\hline 14 & 4 & 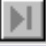 & New Record & Exit \\
\hline
\end{tabular}

Used to enter or view park usage specifics.

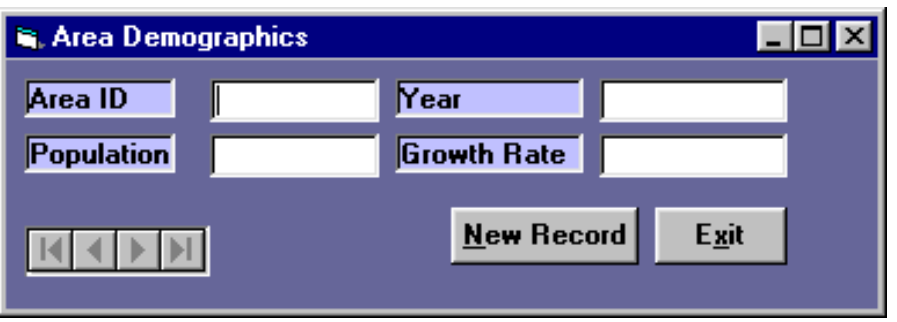

Used to enter or view area demographics.

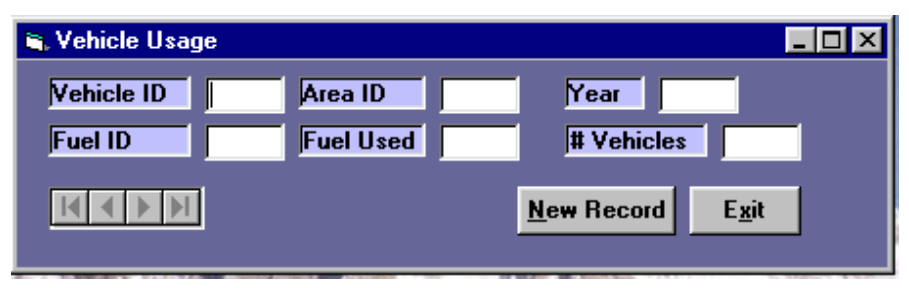

Used to enter or view information about vehicle usage.

\begin{tabular}{|c|c|c|c|}
\hline A Facility Usage & & & - 0 口 \\
\hline Facility ID & Year & & \\
\hline Fuel ID & Capacity & Amt Used & \\
\hline \begin{tabular}{|l|l|l|l|}
4 & $\Delta$ & $\nabla$ \\
\end{tabular} & & New Record & Exit \\
\hline
\end{tabular}

Used to enter or view facility usage information. 


\section{Demonstration of Decision Support Tools for Sustainable Development}

\section{Appendix D-Alternative Fuel Emissions Estimation Basis}

The following information provides the bases for the alternative fuel emissions for conventional and alternative fuels based on non-stationary and stationary applications. All emissions result in units of grams of Carbon Dioxide Equivalent (CDE) which account for greenhouse gas emissions with relevant global warming potential factors applied $\left(\mathrm{CO}_{2}=1.0, \mathrm{CH}_{4}=21, \mathrm{~N}_{2} \mathrm{O}=310\right)$. The referenced emission factors provide an estimate of life-cycle emissions accounting for feedstock production, fuel processing, and vehicle operation.

\section{Non-Stationary Sources (vehicles)}

Greenhouse gas emissions (g CDE) are calculated for non-stationary sources based on a per mile usage rate. Data is provided for near-term (2000-2009) emissions from currently available technology and longterm $\left(2010^{+}\right)$technology improvements for some fuel sources. Emissions data is based on passenger car vehicles. ${ }^{4}$

\begin{tabular}{|c|c|c|c|}
\hline Fuel Type & $\begin{array}{l}\text { g CDE/mile } \\
\text { (based 2005) }\end{array}$ & $\begin{array}{c}\text { g CDE } / \text { mile } \\
\text { (long-term 2010+) }\end{array}$ & Notes \\
\hline Gasoline & $343^{a}$ & & \\
\hline Diesel \#2 & $313^{\mathrm{a}}$ & & \\
\hline Biodiesel (B100) & $67^{b}$ & & $100 \%$ biodiesel \\
\hline Biodiesel (B20) & $264^{b}$ & & $20 \%$ biodiesel \\
\hline Ethanol (E100) & $234^{\mathrm{a}}$ & & $100 \%$ (Corn) \\
\hline Ethanol (E85) & $256^{\mathrm{a}}$ & $63.9^{c}$ & $85 \%$ blend (Corn) \\
\hline$\overline{\mathrm{CNG}}$ & $324^{\mathrm{a}}$ & & \\
\hline LPG & $314^{\mathrm{a}}$ & & \\
\hline Hybrid Electric & $275^{\mathrm{a}}$ & $227.1^{\mathrm{c}}$ & U.S. electric mix \\
\hline Electric & $296^{\mathrm{a}}$ & $239.0^{\mathrm{c}}$ & U.S. electric mix \\
\hline
\end{tabular}

${ }^{4}$ The IPCC methodology provides some size scaling parameters for gas and diesel vehicles. With passenger cars as the baseline, increased $\mathrm{CO}_{2}$ emissions for gas (diesel) powered light trucks are $141 \%$ (139\%) and 363\% (299\%) for heavy-duty trucks. 


\section{Demonstration of Decision Support Tools for Sustainable Development}

a. Source: [Wang, M.Q., Development and Use of the GREET Model to Estimate Fuel-Cycle Energy Use and Emissions of Various Transportation Technologies and Fuels, Center for Transportation Research Energy Systems Division, ANL/ESD-31, March 1996.] Greenhouse gas emissions based on total fuel cycle processes. Fuel applications developed for a 2000 model year car in 2005.

b. Source: [Sheehan, J., et al, An Overview of Biodiesel and Petroleum Diesel Life Cycles, National Renewable Energy Laboratory, NREL/TP-580-24772, May 1998.] The overall life cycle emissions of $\mathrm{CO}_{2}$ from B100 are $78.45 \%$ lower, and B20 is $15.66 \%$ lower than petroleum diesel (313 g CDE/mile).

c. Source: [Wang, M.Q., Greenhouse Gas Emission Impacts of Alternative-Fueled Vehicles: Near-Term vs. Long-Term Technology Options, Center for Transportation Research Energy Systems Division, ANL/ES/CP-92503, May 1997.] Greenhouse gas emissions based on total fuel cycle processes.

\section{Stationary Sources (facilities)}

Greenhouse gas emissions (g CDE) are calculated for stationary sources based on a per gallon usage rate. The emission rates are to be used for all time scales. The rates should be applicable for all scales of stationary fuel uses.

\begin{tabular}{|l|c|}
\hline Fuel Type & $\begin{array}{c}\text { g CDE/gallon } \\
\mathbf{( 2 0 0 0 + )}\end{array}$ \\
\hline Gasoline & $9,610^{\mathrm{d}}$ \\
\hline Diesel \#2 & $10,290^{\mathrm{d}}$ \\
\hline Biodiesel & $9,950^{\mathrm{d}}$ \\
\hline Ethanol (E85) & $5,430^{\mathrm{d}}$ \\
\hline Propane & $5,570^{\mathrm{d}}$ \\
\hline CNG & $2,120^{\mathrm{d}}$ \\
\hline LNP & $5,125^{\mathrm{d}}$ \\
\hline
\end{tabular}




\section{Demonstration of Decision Support Tools for Sustainable Development}

d. Emission calculations are based on Revised 1966 Guidelines for National Greenhouse Gas Inventories, Intergovernmental Panel on Climate Change, 1996. Calculations are based on the IPCC methodology using the key factors and conversions shown in the following table.

\begin{tabular}{|l|c|c|c|c|}
\hline \multicolumn{1}{|c|}{ Fuel Type } & $\begin{array}{c}\text { Fuel Heat Value } \\
\mathbf{( 1 0 0 0 ~ B T U / g a l ) ~}\end{array}$ & $\begin{array}{c}\text { Unit Conversion } \\
\text { English/Metric } \\
\text { (TJ/MMBTU) }\end{array}$ & $\begin{array}{c}\text { Carbon } \\
\text { Emission } \\
\text { Factor (CEF) }\end{array}$ & Oxidized $^{\mathbf{g}}$ \\
\hline Gasoline & $109-119^{\mathrm{e}}$ & $1.0547 \mathrm{E}-03$ & 18.9 & 0.99 \\
\hline Diesel \#2 & $126-131^{\mathrm{e}}$ & $1.0547 \mathrm{E}-03$ & 20.2 & 0.99 \\
\hline Biodiesel & $117-135^{\mathrm{e}}$ & $1.0547 \mathrm{E}-03$ & 20.0 & 0.99 \\
\hline Ethanol (E85) & $81.0-82.5^{\mathrm{e}}$ & $1.0547 \mathrm{E}-03$ & 17.1 & 0.99 \\
\hline Propane & $82.4^{\mathrm{e}}$ & $1.0547 \mathrm{E}-03$ & 17.2 & 0.995 \\
\hline CNG & $25-38^{\mathrm{e}}$ & $1.0547 \mathrm{E}-03$ & 17.2 & 0.995 \\
\hline LNP & $73^{\mathrm{e}}$ & $1.0547 \mathrm{E}-03$ & 17.2 & 0.995 \\
\hline
\end{tabular}

e. Source: [Bechtold, R.L., Alternative Fuels Guidebook, Properties, Storage, Dispensing, and Vehicle Facility Modifications, 1997 Society of Automotive Engineers, Inc., Warrendale, PA, ISBN 0-7680-00521,April 1997.] Average fuel heat values were used in the emission calculations.

f. Standard unit conversion factor of 1.0547 E-03 Terra Joules/Million BTU's.

g. Carbon emission factors and oxidation factors are given in the IPCC documentation.

\section{Verification and Validation of Rates:}

The consistency between emissions rates from non-stationary and stationary sources were verified through use of an example. If a gallon of gasoline (stationary rate of 9,610 g CDE/gallon) is used in a vehicle (using a rate of $343 \mathrm{~g} \mathrm{CDE} / \mathrm{mile}$ ), then the expected mileage is 28 miles per gallon for a year 2000 car. Similarly, a diesel car would be expected to get 33 miles per gallon. These mileage rates appear reasonable, and give validation to the use of the two sets of emission rates. 


\section{Appendix E-External Reviews and Validation}

(Comment letters from Richard Parish and Alicia Birky, NREL)

(Response letter from David Cobb, Bechtel National, Inc.) 